NBER WORKING PAPER SERIES

\title{
THE COMPLEXITY OF LIQUIDITY: THE EXTRAORDINARY CASE OF SOVEREIGN BONDS
}

\author{
Jacob Boudoukh \\ Jordan Brooks \\ Matthew Richardson \\ Zhikai Xu \\ Working Paper 22576 \\ http://www.nber.org/papers/w22576 \\ NATIONAL BUREAU OF ECONOMIC RESEARCH \\ 1050 Massachusetts Avenue \\ Cambridge, MA 02138 \\ August 2016
}

We thank seminar participants at NYU-Stern, AQR Asset Management, ICS of Hitotsubashi University, State Administration of Foreign Exchange (SAFE), Bank of Korea, Shanghai Institute of Finance (SAIF), and Fudan University; and Yakov Amihud, Robin Greenwood, Antti Ilmanen, Michael Katz, Lars Nielsen, Yao Hua Ooi, Lasse Pedersen, Thomas Philippon and Marti Subrahmanyam for helpful comments and suggestions. The views expressed herein are those of the authors and do not necessarily reflect the views of the National Bureau of Economic Research.

NBER working papers are circulated for discussion and comment purposes. They have not been peer-reviewed or been subject to the review by the NBER Board of Directors that accompanies official NBER publications.

(C) 2016 by Jacob Boudoukh, Jordan Brooks, Matthew Richardson, and Zhikai Xu. All rights reserved. Short sections of text, not to exceed two paragraphs, may be quoted without explicit permission provided that full credit, including $\odot$ notice, is given to the source. 
The Complexity of Liquidity: The Extraordinary Case of Sovereign Bonds Jacob Boudoukh, Jordan Brooks, Matthew Richardson, and Zhikai Xu

NBER Working Paper No. 22576

August 2016

JEL No. F3,G1,G12,G15

\begin{abstract}
It is well-documented that government bonds with almost identical cash flows can trade at different prices. The explanation is that due to higher liquidity the most recently issued bond tends to trade at a premium to previously issued bonds. This paper analyzes the cross-section of bond spreads across developed countries over a 17-year time period. Indeed, liquidity has commonality across countries in the expected direction. However, the paper documents a novel finding that questions the standard view of liquidity. Under certain conditions, especially related to credit deterioration and flight to quality, new issue bond spreads tighten and can be negative. In other words, the liquid bonds become cheaper, not more expensive, relative to their less liquid counterparts. We offer an explanation based on price pressure and provide empirical support using data on net flows of investors in sovereign bonds. Of some interest, we are able to reconcile the differential behavior of bond spreads of the U.S. and Germany versus Belgium, Spain and Italy during the Eurozone crisis period.
\end{abstract}

Jacob Boudoukh

The Caesarea Center

Arison School of Business, IDC

3 Kanfei Nesharim St

Herzlia 46150

ISRAEL

jboudouk@idc.ac.il

Jordan Brooks

AQR Capital Management

2 Greenwich Plaza

Greenwich, CT

jordan.brooks@aqr.com
Matthew Richardson

Stern School of Business

New York University

44 West 4th Street, Suite 9-190

New York, NY 10012

and NBER

mrichar0@stern.nyu.edu

Zhikai Xu

Princeton University and

AQR Capital Management

xuzhikai19@gmail.com 


\section{Introduction}

It is now well documented that there are numerous violations of the law of one price for financial assets, i.e., securities with almost identical cash flows can trade at different prices. There is arguably no better illustration of this phenomenon than that of government bonds, in particular, between the pricing of the most recently issued bond and a matched previously issued counterpart. ${ }^{1}$ The extant literature finds the yield spread between newly issued and previously issued bonds (hereby denoted the NI-spread) to be meaningfully positive and time-varying. ${ }^{2}$ The explanation advanced in this literature for the existence of this spread is liquidity. Specifically, investors value the ability to trade the newly issued bonds with immediacy, in relatively large quantities and at the prevailing price (or with a relatively small price impact), and hence are willing to pay a premium for these bonds.

The level and variation of liquidity in the government bond market, however, can arise through a variety of sources, including exogenous transaction costs, demand pressure and inventory risk, and difficulty in locating trading counterparties (see for example the survey by Amihud, Mendelson and Pedersen (2005)). ${ }^{3}$ One of the questions resulting from this literature is the extent to which these sources are common across government bonds: is the NI-spread explained by common liquidity shocks ("flight to liquidity") (e.g., Longstaff (2004) and Goyenko, Subrahmanyam and Ukhov (2011))? A related literature looks at sovereign government bonds of various credit quality and decomposes the sovereign spread into a flight to liquidity and aggregate economy shocks ("flight to quality") (e.g., Beber, Brandt and Kavajecz (2009), Favero, Pagano and

\footnotetext{
${ }^{1}$ See, for example, Cornell and Shapiro (1990), Amihud and Mendelson (1991), Warga (1992), Boudoukh and Whitelaw (1993), Kamara (1994), Elton and Green (1998), Jordan, Jorgensen, and Kuipers (2000), Krishnamurthy (2002), Longstaff (2004), Goldreich, Hanke and Nath (2005), Pasquariello and Vega (2009), and Goyenko, Subrahmanyam and Ukhov (2011). In the U.S., the spread between new and previous bond issues is often denoted the on-the-run versus off-the-run spread.

${ }^{2}$ In the U.S., the spread between new and previous bond issues is often denoted the on-the-run versus off-the-run spread. We choose the NI spread because this terminology is less common in international bond markets for reasons described later.

${ }^{3}$ Some specific theories relevant to the liquidity of the government bond market include Amihud and Mendelson (1986), Grossman and Miller (1988), Boudoukh and Whitelaw (1993), Duffie, Garleanu and Pedersen (2002), Vayanos (2004), Vayanos and Weill (2008) and Pasquariello and Vega (2009), Favero, Pagano and Von Thadden (2010), and Banerjee and Graveline (2013).
} 
Von Thadden (2010), Bai, Julliard and Yuan (2012), Darbha and Dufour (2015), and Pelizzon, Subrahmanyam, Tomio, and Uno (2015)).

In this paper, we study the behavior of the spread between newly issued and previously issued government bonds across a range of countries over an extensive time period, 1998 to 2015. By construction, the spread reflects the relative pricing of government bonds that differ only by issuance date and, importantly, not by credit risk. The behavior of the spread is at times startling and provides a challenge to existing research on liquidity. For example, from 2009 to 2013, the NIspreads of Belgian, Italian and Spanish government bonds are consistently negative. In other words, the price of the liquid newly issued bond falls below the less liquid previously issued bonds. If, in fact, newly issued bonds are more liquid than previously issued bonds, then how can these spreads turn negative? Of course, there exist many time periods when the spreads across countries are positive and move together. Such cases documented in this paper include the default of Russian debt and the so-called LTCM crisis in August of 1998 (i.e., the failure and then bailout of the large fixed income hedge fund, Long Term Capital Management) and, to a lesser extent, the bankruptcy of Lehman Brothers in September 2008.

Our paper provides a framework for understanding these and other stylized facts. In particular, there are two components to the pricing of liquidity, namely (i) the standard benefit arising from lower trading and search costs, and (ii) an ambiguous cost-benefit arising in stressful periods. Current thinking suggests (ii) is a benefit of liquidity as investors "fly" towards liquidity in times of crisis. That is, the NI-spread should widen. However, we document that, in periods of a flight to quality, investors will "fly" from, not to, the liquidity of weak sovereigns. Their NIspreads actually tighten. This is because, under extreme conditions, newly issued bonds are easier to trade than previously issued bonds. Price pressure pushes the price of newly issued bonds more than previously issued bonds.

In equilibrium, investors realize that the newly issue bond of low quality countries could be subject to price pressure episodes, leading to tighter NI-spreads on average in lower quality countries. In other words, a flight episode is a time of high marginal utility. That is, because illiquid bonds of low quality countries can outperform liquid bonds during these episodes, the NIspread is tighter for low quality countries. We document that this is indeed the case; the $R^{2}$ increases from $42 \%$ to $71 \%$ when sovereign CDS spreads are added to a cross-sectional regression of average NI-spreads on a common liquidity factor. 
While the NI-spread is on average smaller for low quality countries, it is a surprising result that this spread turns negative during intense flight to quality periods. Once selling pressure pushes down the price of the newly issued bond, market segmentation can explain why the previously issued bond does not follow suit. The natural arbitrage here would be to buy the cheaper newly issued bond and short the more expensive older bond, but this is difficult to implement due to illiquid bonds being more difficult to short. Moreover, investors are reluctant to transact in older government bonds on the short side because they may get stuck with the transaction (e.g., Graveline and McBrady (2011) and Banerjee and Graveline (2013)). Prices can therefore diverge in segmented markets with heterogeneous investors (e.g., Boudoukh and Whitelaw (1993)). ${ }^{4}$

To some extent, this argument should not be a surprise in the context of the current literature. It is well documented both theoretically and empirically that price pressure can exist in newly issued bonds. For example, the theory of preferred habitat in the U.S. government bond market has been formally derived and resulting supply effects have been empirically confirmed in specific circumstances (e.g., see Vayanos and Vila (2009) and Greenwood, Hanson and Liu (2016) for a theoretical analysis and D'Amico and King (2013) and Greenwood and Vayanos (2013) for empirical studies). Feldhutter (2012) develops a model in which the price of two identical bonds can differ due to search costs and/or selling pressures associated with segmented small and large traders.

The main contribution of this paper is empirical. Using information about global credit risk ("flight to liquidity"), sovereign credit risk ("flight to quality"), and sovereign government bond flows (as a proxy for investor demand for specific maturities), we are able to infer price pressure episodes and explain the remarkable behavior of the NI-spreads. We study a 17-year period compared to previous studies which focus on much shorter time intervals for sovereign government bonds. ${ }^{5}$ The longer period provides much more power to detect liquidity and flight to quality events, including the aforementioned LTCM crisis, the 9/11 terrorist attack, the financial crisis and the Euro crisis, among other episodes. The paper presents novel findings for the relative pricing of sovereign government bonds and may imply broader consequences for the pricing of liquidity.

\footnotetext{
${ }^{4}$ See also Harrison and Kreps (1978), Ofek and Richardson (2003), and Hong and Stein (2003). Alternatively, Greenwood, Hanson and Liu (2016) describe a model in which markets are partially segmented, and, upon one market being hit by a supply shock, the other market is impacted by the supply flows from one market to the other.

${ }^{5}$ For example, the sample epriods include 2002-2003 in Favero, Pagano and Von Thadden (2010), 2003-2004 in Beber, Brandt and Kavajecz (2009), 2006-2012 in Bai, Julliard and Yuan (2012), 2004-210 in Darbha and Dufour (2015) and 2011-2012 in Pelizzon, Subrahmanyam, Tomio, and Uno (2015).
} 
Because we are comparing the spread of likewise government bonds, credit risk is netted out. ${ }^{6}$ The NI-spreads therefore cannot reflect differential default rates, thus, helping isolate the liquidity effect.

First, not surprisingly, we document commonality in liquidity across countries. Correlations across most sovereign bond spreads are positive, averaging 12\%, with some correlations exceeding $50 \%$. The first principal component captures $43.6 \%$ with similarly signed loadings across many countries. These findings suggest a common factor, which we choose objectively as the median country NI-spread. In a regression of NI-spreads on this common factor, we estimate $R^{2} s$ on the order of $27 \%$ (and $38 \%$ with country fixed effects).

Second, while there is evidence in support of the standard liquidity premium (i.e., more recently issued bonds are on average more expensive than likewise bonds), there is a large portion of NI-spread variation that this model cannot account for. Indeed, we document that, for some countries, at the very time one might value liquidity (such as flight to quality as represented by net outflows or deteriorating credit quality), the spreads actually tighten or go negative. Specifically, in a pooled time-series regression of bond spreads on a country's relative credit quality, we document $R^{2}$ s on the order of $13 \%$ (and $20 \%$ with country fixed effects). In other words, liquid bonds become cheaper (more expensive) relative to less liquid bonds when a country's credit condition worsens (improves). We argue and provide empirical evidence that this is due to price pressure more readily showing up in the liquid bond.

Third, we show that this alternative liquidity measure, which is better described as a flight from liquidity, is not due to stale pricing, but rather seems related to selling pressure. We measure this pressure in one of two ways, namely as flows into and out of the sovereign bonds, and as the impulse response of shocks to NI-spreads. The results support the conclusion of temporary price pressure.

Finally, we provide a detailed analysis of various crisis events during the sample period. These crises are estimated objectively and demonstrate two key findings: (1) as expected, crisis events are liquidity events in that the $R^{2}$ s of the empirical liquidity models are much higher during

\footnotetext{
${ }^{6}$ Note that the NI-spread is usually calculated as the difference between the newly issued bond and the most recently issued bond (e.g., Krishnamurthy (2002) and Pasquiarello and Vega (2009)). One of the problems with this calculation is that the previously issued bond can have quite different coupon rates and be of a different maturity depending on the issuance cycle. Here, we construct a new measure of the NI-spread by estimating the parallel shift in the entire off-therun zero curve necessary to price the previous bond. We show that this method has preferable qualities to typical NIspread calculations.
} 
these periods, and (2) less expected, crisis events are quite different in nature with the aforementioned two liquidity components having differential effects.

The paper is organized as follows. In Section II, we describe the data and, in particular, focus on the methodology for comparing recently issued bonds to previously issued bonds. Section III documents the main results of the paper, showing that sovereign liquidity spreads are driven by two components. The first component is common across countries while the second component goes against current thinking. In fact, the spreads tighten when the sovereign runs into trouble and suffers a flight to quality. In Section IV, we provide an explanation provide supporting evidence using a dataset of net flows of sovereign government bonds and time-series patterns of NI-spreads. Section V concludes.

\section{Data Description}

Our primary data source for government bond prices is Data Scope Fixed-Income (DSFI) from Thompson Reuters. We process a total of 3261 treasury bonds and 6005 treasury bills issued by the ten largest issuers from developed countries: Belgium, Canada, France, Italy, Germany, Japan, Netherlands, Spain, UK and US. The dataset starts in 1993 but actual start dates vary by country. For European countries, DSFI does not contain complete price history for a large number of bonds issued pre-euro. We use Bloomberg as our secondary data source when DSFI data is unavailable or discontinuous. ${ }^{7}$

The purpose of this paper is to study liquidity in sovereign bond markets by comparing the most liquid issue to a closely related but less liquid issue. In previous studies, especially involving U.S. Treasury markets, this was paramount to comparing the most recently issued to the second most recently issued bond. International sovereign markets present an important institutional challenge to the common procedure which needs to be addressed. In particular, unlike in the United States, a number of countries do not continually issue new bonds, but rather, reissue existing ones. In these cases we need to identify not only the issuance date of each bond, but also reissuance (also known as re-openings) dates and quantities for each of the candidate bonds. Since most reissuances are simply those of the existing most recently issued bond, the reissuance itself generally does not

\footnotetext{
${ }^{7}$ DSFI is the standard data source for marking books of portfolio managers, mutual fund administrators and custodians, among others. Thompson Reuters sources the data from various primary sources such as the Bridge EJV database and broker-dealers. In comparing the pricing of bonds using Thompson Reuters versus Bloomberg, weekly correlation of bond price changes of newly issued and most recent previously issued bonds average $98.5 \%$ (with a low of $97.1 \%$ for Japanese bonds).
} 
alter our identifying of the most liquid newly issued bond. In instances where this is not the case, i.e., the reissuance is not of the most recently issued bond, we have to take into consideration the quantity that was issued. Intuitively, a small re-opening does not make a bond the most liquid one, while a large one does. We define "large" to be a reissuance of $70 \%$ or more of the original amount issued when the bond was first auctioned. The results largely are robust to this choice. We classify a bond with remaining time-to-maturity between 8.5 and 11.5 years to be part of the 10 year bond cohort. In order to determine the appropriate cohort, we consider the remaining time-to-maturity at the last point in time that the bond was reissued as its tenor. For all ten government issuers, we are able to identify the 10-year newly issued bond for the entire sample period.

Table 1A documents properties of the issuance cycle for the 10-year newly issued bond. The number of newly issued 10-year bonds range from a low of 19 for Canada to a high of 144 for Japan. Related, the average issuance cycle is 363 days for Canadian bonds while just 45 days for Japanese bonds. As a frame of reference, the U.S. has 81 newly issued 10-year bonds in our sample, with an average issuance cycle of 104 days. As mentioned above, rather than issuing a new bond, some countries simply reissue an existing bond. Table 1B documents the properties of the reissuance cycle. For 9 of the 10 countries in our sample, a majority of a country's bond reissuance occurs within 6 months and 90\% within 9 months of the original issue. As an illustration, consider Italy. Italy issues $27 \%$ of the total issuance of a bond at initiation, then cumulative $39 \%$ up to 1 month after issuance, $61 \%$ up to 3 months, $88 \%$ up to 6 months and $93 \%$ up to 9 months. In comparison, the U.S. issues $47 \%$ of the total issuance of a bond at initiation, $74 \%$ up to 1 month after and $99 \%$ up to 3 months after. Table $1 \mathrm{~B}$ confirms the assertion above that most reissuances are simply those of the existing most recently issued bond. Moreover, Table 1B shows that, 6 months after a new issue, governments tend to issue a new bond, thus starting the cycle over. Table 1B shows that, other than the U.K., this characteristic holds across all sovereign bond issuance. ${ }^{8}$

The fact that in general newly issued bonds are more liquid than previously issued bonds is documented in a number of papers, e.g., Fleming (2003), Pasquariello and Vega (2009) and Govenko, Subrahmanyam and Ukhov (2011). In particular, as a measure of liquidity, the spread between the most recently issued bond and previously issued bonds is related to differences in the bid-ask spreads of these bonds. As expected, the newly issued bonds' bid-ask spreads are tighter

\footnotetext{
${ }^{8}$ As shown later in the paper, there is differential behavior of NI spreads pre- and post-financial crisis. Table 1C repeats the new issuance calculations for the period post-crisis, and shows that there are no significant differences to the pre-crisis period.
} 
than older counterpart bonds. While this finding is intuitive, it would be useful to document such evidence for our sample of bonds. Unfortunately, bid-ask data only becomes available for our cross-section of bonds late in the sample, on October 30, 2013. Nevertheless, Table 2 documents results for this shorter sample.

Most important, for 9 of the 10 countries, the average bid-ask spread of the two most recent previously issued bonds is higher than that of the newly issued bond. ${ }^{9}$ Intuitively, the most recently issued bond should be more liquid and this is confirmed by bid-ask data albeit over a shorter time period. Moreover, for 7 of these countries, the difference is significant at $10 \% p$-values and, for 5 countries, at 5\% p-values. As additional evidence, Table 2 documents that the newly issued bond also has a lower bid-ask spread the majority of the time for 9 of the 10 countries, ranging from 59\% to $86 \%$ of the time. It should be noted that there are periods when the bid-ask spreads are the same. Independent of the above point on the relative liquidity between newly issued and previously bonds, the absolute level of the spreads are quite small. For example, for the United States 10-year bond market, the quoted spreads are 0.23 basis points for the new issues versus 0.28 basis points for the recent previous issues.

\section{a. The New Issue Spread}

The goal of this paper is to analyze the spread between likewise sovereign government bonds that differ only by their liquidity. As described in the introduction, there is a considerable literature focusing primarily on the United States Treasury bond market that compares the yields of the newly issued versus the next most recently issued comparable bond. As Table 1 shows, other than Japan, the issuance cycle is considerably longer for other country's 10-year bonds. This lengthy cycle makes the comparison problematic. The reason is that if the term structure of interest rates is not flat, then the difference in maturity may be significant enough to obscure the liquidity premium inherent in the yield spread between the newly issued and the most recent previously issued bond. Table 3A documents the properties of the yield spread country by country.

To the above point, for all the countries, except the U.S., the average yield spread is actually negative. If the term structure is upward sloping over this period, and there is a sufficient gap in the issuance cycle, then there will be a bias towards a negative spread. In order to

\footnotetext{
${ }^{9}$ For this time period (i.e., post October 2013), the exception is Germany. For the majority of this period, the latest previous issue to the newly issued 10 -year bond was the cheapest-to-deliver bond in the corresponding futures contract, thus, adding to its liquidity.
} 
understand how important the bias is, note that the yield difference between the newly issued bond and most recent previous issue is a combination of local slope of the yield curve and the liquidity premium of the new issue (or illiquidity discount of the older issue). We use the curve based on prices of previous issues to price the newly issued bond and compute its hypothetical yield if it were priced by the curve in line with previous issues. We construct the local slope measure as the most recent previous yield minus the hypothetical new issue yield. Liquidity aside, this slope measure captures the impact of time-to-maturity differences between the newly issued and previously issued bond.

Table 3B reports regressions of the previous issue minus new issue yield spread on this local measure of the term structure slope, as well as estimates of duration and convexity. The coefficient on the term structure slope is 0.85 and explains an astonishing $59 \%$ of the variation of the yield spread. Country fixed effects add just a fraction to the explained variation. Table 3B shows that the yield spread is related to the difference of duration and convexity. However, conditional on local slope, the relationship drops substantially. This reassures the thesis that a large part of the yield spread is explained by the slope of the term structure and cash-flow differences between the two bonds.

The results of Table 3 suggest that, outside of the United States, any analysis of the spread between new issues and the most recent previous issue will be difficult in light of the importance of the coupon and maturity mismatch. This is a well-known issue in trying to match bonds of different liquidity. (See Fleming (2002), Longstaff (2004) and Schwartz (2010).) For example, Longstaff (2004) compares Refcorp and Treasury bonds in the U.S. as a way to isolate liquidity because neither bond issues have credit risk. To adjust for the maturity mismatch, he creates constant maturity yields based on constructed zero curves from Refcorp and Treasury bonds across available maturities. The yield spread thus is relatively insensitive to term structure characteristics. We follow a similar strategy here.

In particular, we pool together all the applicable previously issued bonds of a given country. We then bootstrap a zero curve using only these bonds. ${ }^{10} \mathrm{We}$ compute a hypothetical price for each

\footnotetext{
${ }^{10}$ First, we group the bonds into different tenors $(2,3,5,7,10,15,20,30)$ by their time-to-maturity as of their most recent issuance. We remove the newly issued bond for each tenor as well as the aged ones (e.g., a 7 year bond having a time to maturity shorter than any of the 5 year bonds). Then we apply a standard bootstrapping procedure for all the onthe-run T-bills and the selected bonds with linear forward rate interpolation to obtain zero curves. By construction, the spread of the newly issued bond and a likewise hypothetical bond from this zero curve will generally be nonzero since the newly issued bonds are not included in the bootstrapping procedure.
} 
of the newly issued bonds assuming these bonds are priced by the same zero curve, discount factors. The spread between the hypothetical bond (based on the previous issue curve) and the newly issued bond, denote NI-spread, is defined as the shift in the zero curve that would price the

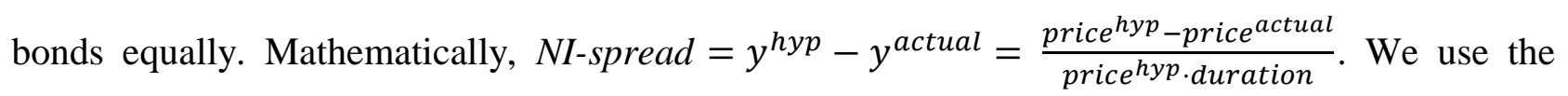
Fisher-Weil duration to capture the price sensitivity to the parallel shift of the yield curve (e.g., Fisher and Weil (1971)). Intuitively, the NI-spread has the interpretation of the number of basis points the yield curve has to shift down so that the newly issued bond can be priced by the curve. A positive spread represents the premium newly issued bonds are priced at relative to a duplicate bond constructed from the term structure of older bonds.

Table 4 documents the properties of the NI-spread of the 10-year bond country by country. In contrast to the results of Table $3 \mathrm{~A}$, Table $4 \mathrm{~A}$ documents that the spread is on average positive for all countries except Japan. The positive spread is consistent with a premium for holding previous bond issues compared to newly issued bonds. The range of average spreads varies from a low of -0.4 basis points for Japan to a high of 4.8 basis points for the U.S. It is worth commenting on two other features of the NI-spread. The first is that the NI-spread has considerable variation over the time period, with volatilities on the order of several basis points, and extremes ranging from both negative to positive spreads. The second is that the NI-spreads are persistent, dying out slowly over a number of months. For example, on average, the autocorrelations at 1-week, 1-mth, 3-mth, and 6-mths are respectively $0.88,0.68,0.47$ and 0.35 .

Table 4B reports an analogous analysis to that of Table 3B by regressing the NI-spreads on our local measure of the term structure slope, as well as estimates of duration and convexity. The coefficient on the term structure slope is now -0.14 and, net of country fixed effects, explains only $3 \%$ of the variation of the NI-spread. Country fixed effects now add approximately $13 \%$ to the variation, suggesting that there are built-in-differences of the liquidity premium across countries. Duration and convexity measures alone do not add much to the explained variation of NI-spreads though the duration measure comes in significant, especially with fixed effects. In contrast to the results of Table 3B, our conclusion is that the NI-spread is not explained by the slope of the term structure which is to be expected given the NI-spread, by construction, matches maturity and cash flows. 
As a comparison between the NI-spread and the more standard previous issue minus new issue spread, Figures 1 graphs the two spreads over the time period for all ten countries. The slope between the 10-year and 2-year bonds is also provided for each country. The slope is labelled on the right-hand side of the figure whereas the spreads are labeled on the left-hand side. For visualization purposes, note that the term structure is presented as the opposite of the usual slope, i.e., 2-year minus 10-year. Consider the United States, Germany and Italy. It is quite apparent that, especially for the U.S. and Germany, the difference between the two bond spreads widens when the term structure slope steepens. While this result visually confirms the regressions of Table $3 \mathrm{~B}$ and Table 4B, an additional observation from Figure 1 is that the spread measures track each other

quite closely when the term structure is flat. This result is comforting to the extent it suggests the two measures are capturing a common effect, namely liquidity. With respect to Italy (and, for that matter, Belgium and Spain), note that there is a considerable period from 2009 to 2013 in which both spread measures are negative. This period coincides with the Euro crisis and, in particular, the sovereign debt crisis of the Eurozone periphery, including Italy and Spain (and to a lesser extent Belgium). Of course, the spreads, by construction, have no exposure per se to credit risk, so the credit difficulties of Italy, Spain and Belgium must be proxying for other relevant market conditions.

\section{III.Empirical Results: The Liquidity Across Sovereign 10-Year Bonds}

While the NI-spread on average captures the positive spread between previously issued and newly issued bonds, a perusal of the NI-spread, however, shows that the spread is sometimes negative, and varies both through time and cross-sectionally. Other than measurement error, what can explain such behavior of the NI-spread?

As a first pass at the NI-spread data, Table 5A documents the unconditional variancecovariance matrix of the NI-spreads between the 10 countries in our sample. Some striking characteristics are apparent. First, as expected, the correlations are on average positive in the crosssection, namely 0.12 . Nevertheless, if there is a common global liquidity factor, it is either small or offset by other factors. For example, across the 45 correlations, the range goes from a low of -0.25 (between Italy and Germany.) to a high of 0.53 (between the U.K. and U.S., and Belgium and Italy). Second, to the extent there are economically significant correlations, these correlations 
suggest an interesting pattern. For example, the Germany NI-spread tends to be negatively correlated with other countries in Europe (such as Belgium, Spain, France and Italy), yet mildly positive with the Americas (such as Canada and the U.S.). At first glance, this seems surprising as one might expect that Europe would be subject to a more common liquidity factor. Indeed, the NIspreads of Belgium, Spain, France and Italy are all positively correlated.

As further evidence, Table 5B provides the first three principal components of these ten developed countries. The first principal component captures almost $44 \%$ of the total variation of NI-spreads. To the above point, the first component loads in a similar sign across most of the countries with a heavier weight on Belgium, Spain and Italy. The key driver of NI-spreads appears to be a mix of a common factor with added weight on the weaker sovereigns. As we explain below, this effect can be explained in the context of a simple empirical model which highlights a perverse cost to holding the liquid bond in periods of stress.

\section{a. Does "Flight to Quality" Lead to "Flight from Liquidity"?}

Below, we present an empirical model for why the above surprising correlation pattern exists. As a preview, in this subsection, we explain the variation of NI-spreads in terms of a "flight to liquidity" factor plus "flight to quality" in the form of credit quality differences across countries. Note that by construction NI-spreads do not have any credit risk embedded in them as the spread represents the difference of government bonds within a country, that is, bonds with the exact same credit quality (albeit of different liquidity). Thus, any explanatory power of credit quality for NIspread pricing must be due to credit quality across countries proxying for some other characteristic of sovereign bond markets. The novel finding is that a "flight to quality" can represent a "flight from liquidity" in those countries experiencing credit risk and suffering outflows of relevant investors. In other words, in times of crisis, rather than increase, NI-spreads actually decrease and can turn negative in high credit risk countries as investors put pressure on the most saleable assets, namely the newly issued benchmark bonds.

The standard equilibrium argument for the existence of a liquidity premium is that investors value the ability to transact large amounts of a financial assets quickly at little or no cost. In times of financial stress, when there is a common shock to liquidity and it dries up, there is a large differential in this ability for liquid and illiquid financial assets. Given that there is a probability of 
financial stress over the life of these financial assets, markets levy a significant premium for holding the liquid asset.

This paper suggests the equilibrium is more complicated. In time of financial stress, there may also exist a flight to quality, namely a desired shift from one set of financial assets to another. In our example, the shift is from low credit sovereign bonds to high credit sovereign bonds. Investors use liquid bond issues to sell out of the low quality sovereigns precisely because they can transact larger amounts quickly, leading to price pressure on these bonds. Investors recognize the underperformance of liquid bonds in low quality countries and, consistent with a risk-based story, trade them at a relative discount.

In order to capture these two differential effects, we need to construct two observable variables that simultaneously capture the "flight to liquidity" and "flight to quality". With respect to "flight to liquidity", we follow a standard procedure. We model a common component to liquidity, $F_{t}$, by taking the median NI-spreads, $F_{t}=$ median $\left(\left\{N I_{i t}\right\}_{i}\right)$. In theory, if there does exist a common component, then the cross-sectional median will uncover it if the sensitivity is similar across countries. ${ }^{11}$

Note that a typical measure of the quality of the sovereign is its credit default swap (CDS) spread and we use the CDS spread as a measure of "flight to quality". We argue that credit quality has pricing implications for the sovereign bond's liquidity, independent of credit risk. The basic idea is that marginal investors fly to and away from an asset depending on its quality. We choose $\left(C D S_{i t}-\frac{1}{N} \sum_{i}^{N} C D S_{i t}\right)$ as a measure of the relative credit quality across the $N$ countries. In other words, our measure of "quality" proxies for the idiosyncratic portion of a sovereign's credit, namely the difference between a given sovereign's CDS premium and the average cross-sectional premium across the countries. Note that this explanatory variable, the relative CDS spread of the sovereign (against a cross-sectional average), is the same one as that used by Beber, Brandt and Kavajecz (2008). In contrast to our use of this variable, however, they use it as their measure of credit risk of the sovereign bond. Specifically, in conjunction with various liquidity measures, they attempt to decompose the spread between sovereign bonds and euro swaps into a credit and

\footnotetext{
${ }^{11}$ Note that the median spread is still subject to the well-known bias in deriving factors from the dependent variable. That is, even if there is no systematic component to $N I_{i t}$, some relationship will still exist due to $N I_{i t}$ impacting the median across $\mathrm{N}$ different $N I_{i t}$. If $\mathrm{N}$ is large enough, however, the sensitivity of each $N I_{i t}$ to the factor $F_{t}$ will be small.
} 
liquidity component. Their sample is short, covering just April 2003-December 2004. Nevertheless, they find strong evidence that the majority of sovereign yield spreads is driven by credit quality though liquidity also matters in times of increased market risk, especially in low credit risk countries.

With respect to "flight to quality", standard thinking is that it is closely linked to "flight to liquidity". In particular, it is argued that there is a preference for liquidity in times of stress. This leads to liquidity premia increasing during these "flight to quality" periods (e.g., Vayanos (2004)). There is growing empirical support for the existence of this link in a variety of markets, including the U.S. Treasury bond market (Goyenko, Subrahmanyam and Ukhov (2011), across credit-free markets in the U.S. (Longstaff (2004)), and the Euro-are government bond markets (Beber, Brandt, and Kavajecz (2009)). For example, as mentioned above, Beber, Brandt, and Kavajecz (2009) document that even though spreads of sovereign bonds against the Euro-swap benchmark are primarily driven by credit quality of the sovereign, liquidity plays an important pricing role during times of high uncertainty. Darbha and Dufour (2015) and Pelizzon, Subrahmanyam, Tomio and Uno (2015) also document a relationship between credit quality and liquidity. In contrast, Favero, Pagano and Von Thadden (2010) argue, and present evidence, that a "flight to quality" does not necessarily lead to a "flight to liquidity". Rather, they argue that an aggregate risk factor drives sovereign yield spreads which, if not accounted for, can mistakenly link "quality" to "liquidity".

In this paper, we provide an alternative explanation by linking "quality" and "liquidity" to the relative pricing of government bonds. Specifically, consider the following regression model:

$$
\mathrm{NI}_{i t}=\alpha+\beta_{i} F_{t}+\gamma\left(C D S_{i t}-\frac{1}{N} \sum_{i=1}^{N} C D S_{i t}\right)+\varepsilon_{i t}
$$

Regression equation (1) allows us to ask how much of the variation of the NI-spread both through time and across countries can be explained by the countries' relative credit quality and a common factor. The coefficient on the liquidity factor is allowed to vary across countries, while the coefficient on the quality factor does not vary, albeit the quality factor itself varies across countries and time. The regression methodology is a pooled, time-series analysis of 10 countries' 10-year NIspread over the period 1998 to 2015.

The data on CDS for each country comes into the sample at different times. For example, the first countries, Italy and Belgium, come in January 31, 2001 while the last countries, U.S. and U.K., enter on December 1, 2003 and March 20, 2006, respectively. In order to take advantage of 
the entire sample, including the LTCM crisis in the summer and fall of 2008, we backfill the CDS by using a CDS-implied level based on country ratings. Specifically, we regress CDS on ratings during the period of available CDS data; we then take the coefficient from the regression and the ratings during the prior period to estimate an implied CDS level; and, finally, to keep the CDS data continuous, we shift the implied CDS level to the true CDS level when it enters the sample. The results are reported for both the entire and the CDS-specific samples.

Table 6 provides results for regression equation (1). In particular, the column labelled 1 and 2 of Table 6 document the results of the regression just using the common factor. The $R^{2}$ is $27.0 \%$ and the coefficients on the factor are significant and positive (with Japan being the exception). Interestingly, the most sensitive NI-spread to the common factor is that of the U.S., namely 1.91. In other words, the spread between newly issued and previously issued bonds is greatest for the U.S. This finding is consistent with the "safe haven" nature of the United States and previous research on the on-the-run versus off-the-run spreads of U.S. Treasuries. That said, when country fixed effects are included in the regression, the coefficients on the U.S. and most other countries (Italy being the exception) shrink towards one. In the U.S. case, its mean NI-spread is higher than any of the other 9 countries.

Columns 3-6 of Table 6 document the regression equation (1) just using the quality variable, $\left(C D S_{i t}-\frac{1}{N} \sum_{i}^{N} C D S_{i t}\right)$. Without country fixed effects (column 3 ), the $R^{2}$ is $13 \%$ and the coefficient on CDS quality is negative and statistically significant. Indeed, the sign of the coefficient suggests that if a country's credit quality is relatively low, that is, $\left(C D S_{i t}-\frac{1}{N} \sum_{i}^{N} C D S_{i t}\right)>0$, then its NI-spread will be lower. The coefficient, -0.03 , implies that for every 100 basis points of additional CDS premium the NI-spread will fall by 3 basis points, or, in return space, approximately 20 basis points for 10-year bonds. A nice finding from Table 6, however, is that the intercept is positive, implying a positive average NI-spread.

Columns 4-6 of Table 6 imply two additional points. First, with fixed effects, the $R^{2}$ jumps to $20 \%$. The large increase is not surprising given the coefficient on a country's credit quality does not vary across countries. The variation in country betas on the common factor suggest some crosssectional adjustments are needed. Second, columns 5 and 6 extend the sample back to 1998 using the aforementioned implied CDS measure. The coefficient on flight to quality remains at 0.03 , but 
the $R^{2}$ drops from $13 \%$ to $8 \%$ for the longer sample without fixed effects and $20 \%$ to $16 \%$ with fixed effects. The drop is most likely related to the noise associated with the use of ratings-based implied CDS rates and the fact that the later sample includes more examples of flight to quality and thus more variation of the explanatory variable.

Columns 7 and 8 show the results from regression (1) over the full sample with both the common liquidity factor and the flight to quality factor included. Some observations are in order. First, without fixed effects, the $R^{2}$ is an impressive $35 \%$. In other words, a common liquidity factor and a flight to quality factor can explain a substantial proportion of the cross-section and timeseries of the NI-spreads across countries. Second, in terms of the coefficients and statistical significance, both maintain their magnitudes and t-statistics when both factors are included. For example, the $t$-statistics on the flight to quality factor increase from -3.90 (column 5) to -4.00 (column 7), while the average absolute value of the t-statistic on the common factor increases from 5.32 (column 1) to 5.64 (column 7). Third, that regression equation (1) can fully explain the crosssection seems a tall order. Credit quality aside, there might be specific characteristics of the liquidity of each country's bond market that is not common across countries. Column 8 of Table 6 presents regression equation (1) with country fixed effects. While there is no change in the coefficient on credit quality or the common liquidity factor, the $R^{2}$ does increase to $41 \%$, confirming important differences across countries. Finally, not shown in Table 6, the residual correlations from regression (1) are much lower than those presented in Table 5. As an illustration, the first principal component of the regression residuals of the NI-spreads explain $24.3 \%$ of the variance compared to $43.6 \%$ for the raw NI-spreads.

An alternative approach to the pooled time-series analysis provided in Table 6 is to look at the cross-section of average NI-spreads. Figure 2 plots the average NI-spread for the ten developed countries against (i) the factor loading of the NI-spreads on $F_{t}$ from Table 6, scaled by the average of the common liquidity factor, and (ii) this variable plus the average of $\left(C D S_{i t}-\frac{1}{N} \sum_{i}^{N} C D S_{i t}\right)$ for each country, scaled by the pooled regression coefficient from Table 6. There is a clear positive relationship between the average NI-spreads and the common liquidity premium, with an $R^{2}$ of $42 \%$. There are a few outliers, such as Italy which has a high common liquidity factor loading yet low average spread. However, when the average NI-spreads is graphed against both the common liquidity premium and "flight to quality" premium, the $R^{2}$ jumps to $71 \%$. All the countries" 
premiums correspond closely to their NI-spreads. This is consistent with the aforementioned equilibrium interpretation, namely liquid bonds on average trade at a relative discount to illiquid bonds for low quality versus high quality countries because of the risk of price pressure in times of distress.

Intuitively, the results of Table 6 and Figure 2 suggest that liquidity can be a curse in that, during times of crisis, "flight to quality" can lead to a "flight from liquidity". The liquidity of the newly issued bond is not just about the premium investors pay for the ability to transact, but also about receiving compensation for suffering price pressure episodes when the investor most wishes to sell the bond. Ironically, illiquid bonds do not reflect this pressure because investors are

reluctant to transact, especially on the short side, because of getting stuck in the trade. This tradeoff between standard notions of liquidity and flight to quality impact the pricing of bonds at all times. This is because rational pricing is based on expectations of future liquidity events and flights to quality. That said, it is reasonable to presume that these expectations are highest during crisis-like periods. In the next section, we explore regression equation (1) during various crises.

\section{b. Flight to Liquidity, Flight to Quality and Crises}

As a first pass at comparing the pricing of NI-spreads in different crisis periods, we break the sample into pre- and post-2008 financial crisis. Table 7A and 7B report the results from regression equation (1) for both periods respectively. Consider first the pre 2008 period provided in Table 7A. As seen from columns 1 and 2, the common liquidity factor explains 27\% (and 38\% with fixed effects) of the variability on its own; has a positive loading on all countries except Japan; and these loadings are all statistically significant. These results coincide with our standard notion of liquidity. In contrast, the flight to quality factor is still negative and statistically significant, albeit with a lower $R^{2}$ of $13 \%$ (20\% with fixed country effect) documented in columns 3-6. Compared to the full sample, the coefficient is more negative, most likely due to the much lower variability of CDS spreads during the pre-2008 period. Perhaps most interesting, when combining the two factors together, there is not a large jump in the $R^{2}$. This suggests that the positive coefficient on common liquidity and the negative coefficient on flight to quality are capturing similar phenomenon with NI-spreads. 
The results post 2008 provide a useful comparison. First, and foremost, the common factor plays a much smaller role in term of explanatory power with $R^{2} \mathrm{~s}$ of just $5 \%(29 \%$ with fixed effects). The coefficients on the common factor are still all positive except only 5 of them have tstatistics significant at conventional levels. Second, the flight to quality factor on its own has a negative coefficient which is statistically significant. The $R^{2}$ is $14 \%$ (25\% with fixed effects). This is important given that the regression uses just one loading on one variable to try and explain the cross-sections and time-series patterns of NI-spreads during an exceptional sub period. Comparing the two samples, the flight to quality factor is quite consistent in terms of the coefficient sign, statistical significance and $R^{2}$. Finally, in contrast to the early sample, the full regression equation (1) provided in columns 7 and 8 show that the common factor and flight to quality factor are picking up additional phenomena during the financial crisis period. Most telling, the individual $R^{2} \mathrm{~S}$ of $5 \%$ and $14 \%$ (in columns 1 and 3) jump to a combined $R^{2}$ of $23 \%$ (in column 7). The fact that the combined $R^{2}$ exceeds the sum of the individual $R^{2}$ s of $19 \%$ suggests that the common liquidity factor may be negatively correlated with flight to quality in the pooled time-series.

The contrasting behavior of the co-relation between common liquidity and flight to quality in the two samples implies that not all liquidity crises are the same. In order to dig a little deeper, we break the sample period from 1998 onwards into crisis and non-crisis periods. In order to be objective in terms of defining a crisis period, we first take the St. Louis Fed Financial Stress Index as a starting point (Klieseen and Smith (2010)). In brief, the index is based on the first principal component of 18 weekly data series which have all been standardized, covering 7 interest rate series, 6 yield spreads and 5 other indicators (such as volatility and equity series). The primary assumption is that the main common factor across the 18 series is financial stress. In order to convert this index into crisis periods, we create a rolling 1-year standard deviation of weekly changes in the index and define a crisis as any period outside of 3 standard deviations from the norm. Figure 3 plots the crisis periods over the full sample. For our purposes, the crisis periods map well to intuition, with the LTCM and Asian contagion crisis, the DotCom and 9/11 terrorist attack, the initial pre-financial crisis period including the summer of 2007, the financial crisis starting with Lehman's bankruptcy, and the Euro crisis in 20011-2012 (albeit perhaps shorter than expected), all being captured by the methodology.

Table 8A runs regression (1) during crisis periods only. A little over one-third of the sample is defined by a crisis. The results are consistent with the full sample regression of Table 6 
albeit somewhat stronger. For example, the coefficients on the common factor are strongly positive and negative on the flight to quality. Moreover, without fixed effects, the $R^{2} \mathrm{~s}$ on the common factor and flight to quality respectively are $31 \%$ and $20 \%$, and $42 \%$ for the combined regression. In terms of the pricing of NI-spreads, we argued earlier that these two factors rationally drive the NI-spreads in all periods because of the likelihood that a liquidity or flight to quality episode could occur at any. That said, it is comforting that, during periods when these episodes are more likely such as the crises defined in Figure 3, the NI-spread regressions are more dramatic.

The pre- and post-crisis regressions, however, of Table 7 implied that not all crises are the same. It is quite possible that one crisis may be driven more by a shock to the common liquidity factor and another by a shock to credit quality of various countries. To investigate this in more detail, Tables $8 \mathrm{~b}$ and $8 \mathrm{c}$ break the crisis periods into pre-2007 crises (including that of LTCM) versus post 2007 crises. We choose the LTCM period because it is generally considered a period that did not involve large moves in the credit quality of developed countries. Before discussing the results, note that for the LTCM sample, we rely solely on the implied CDS spread based on ratings. The LTCM crisis is very much captured by a common liquidity factor with positive coefficients across countries (except Japan) and a high R-squared of 54\% (60\% with fixed effects). The flight to quality factor, however, also explains variability of the NI-spreads. The $R^{2}$ is a reasonable $12 \%$ with a significant statistically negative coefficient though it should be stated that the factor drops out once fixed effects are included. The combined regression, however, is dominated by the common liquidity factor, confirming the standard intuition that the LTCM crisis was a common liquidity shock. The cross-sectional and time series behavior of NI-spreads is consistent with this intuition.

More novel are the findings for all the other crisis periods (with LTCM excluded). Without fixed effects, the common liquidity factor explains very little of the variation with an $R^{2}$ of just $1 \%$. Only 2 of the 10 loadings are statistically significant albeit 7 of the 10 are still positive. With fixed effects the $R^{2}$ jumps to $38 \%$ with $4-5$ of the 10 coefficients borderline significant. This finding suggests that these other crises were primarily cross-sectional in nature. The flight to quality factor confirms this result with an $R^{2}$ of $20 \%$ (38\% with fixed effects) and a statistically significant negative coefficient on the factor. In other words, these other crises were primarily driven by crosssectional variation in NI-spreads due to differing credit quality; that is, the NI-spreads did not move together during these crises but apart depending on their countries' relative credit quality. When 
the common liquidity factor and flight to quality are combined, the increase in $R^{2}$ is incremental, i.e., from $1 \%$ and $20 \%$ respectively to a combined $23 \%$ suggesting again a role for both factors.

\section{Understanding Flight to Quality}

Section 3 lays out evidence in support of two pricing factors for NI-spreads across countries and through time. The first is a common liquidity factor, and the second is a country specific flight to quality factor. There are two main takeaways.

First, there is a premium for liquidity, since investors value the ability to transact quickly in significant amounts with little or no transaction cost. This premium may differ across countries because some countries offer a more liquid market for their newly issued versus older bonds. This

premium is generally positive and is represented by the fixed effects in Tables 6-8. During times of crisis, there may be liquidity shocks which make newly issued bonds substantially more liquid than older bonds. This generally increases the NI-spread across all countries. The sensitivity to this liquidity shock may vary depending on a particular country's characteristics. Tables 6-8 generally support this factor by showing (a) positive coefficients on the common factor, (b) variation in the coefficients across countries, and (c) large $R^{2}$ s.

Second, and most notably, during times of crisis, there may also be credit quality shocks resulting in some countries' bond markets becoming distressed relative to other countries. The results in this paper are novel because we show that there is an impact on NI-spreads even though the bonds have the same default risk. The results documented in Tables 6-8 show that NI-spreads tighten for low quality countries and widen for high quality ones. In other words, the liquidity premium actually decreases the lower the credit quality of the country is. This extraordinary result begs the question - what is the possible explanation?

Our argument for this latter finding is that, during these crisis periods, investors transact in the most liquid securities available and try and shift their holdings to high quality assets, i.e., flight to quality. Price pressure then pushes down (up) the price of the most liquid securities in low (high) credit quality countries. This theory leads to several additional implications that deserve scrutiny. If price pressure can explain the NI-spread, then we should expect to see that, (i) in times of capital flows from "marginal" investors, the flight to quality factor should be responsive to these flows, 
and (ii) during price pressure episodes, shocks to the NI-spread should be temporary and driven by newly issued, rather than previously issued bonds.

Alternatively, the behavior of the NI-spreads could in theory be explained by stale pricing of the older bonds. When credit quality of a country deteriorates and investors move out of the country's government bonds, the NI-spread can turn negative if the prices of the newly issued bonds fall and, due to staleness, there is no corresponding move in the previously issued bonds. We first address this issue.

On the surface, there are tworeasons why staleness is unlikely to be a plausible explanation for the behavior of NI-spreads. First, the NI-spreads and country credit quality are persistent over several months. For example, other than Japan, the autocorrelation of NI-spreads range from 0.83 to 0.93 at 1 week, 0.67 to 0.87 at 1 month, and 0.32 to 0.72 quarterly. Idiosyncratic CDS spreads persist even more, ranging from 0.96 to 0.99 at 1 week, 0.88 to 0.97 at 1 month, and 0.72 to 0.93 quarterly. In contrast, staleness would induce mean-reversion over relatively short horizons.

Second, staleness in the older bond prices should show up as a lead-lag relation between the older and newly issued bonds but not vice versa. Table 9 documents the weekly autocorrelation and cross-autocorrelations changes in the yields of the newly issued and its hypothetical older counterpart. There is no evidence of staleness of the older bond relative to newly issued series. The cross-autocorrelation between lagged new bond yield changes and old bond yield changes are actually negative (albeit small) for 9 out of the 10 countries, the opposite implication of staleness. There is some slight evidence of negative autocorrelation of yield changes for both newly issued and older bonds. While such a negative autocorrelation is consistent with stale pricing under a random walk model, it is also consistent with mean-reversion under temporary price pressure (and no stale pricing). Moreover, while the autocorrelations are quite similar for both the new and old bonds, the new bond has a more negative autocorrelation in 4 of 9 cases, equal in 3 cases and less negative in only one case. If anything, this finding suggests that the time-series properties of the NI-spread are more likely driven by the newly issued bond.

To investigate the mean reversion properties of NI-spreads more closely, we run a threshold autoregressive model (e.g., Tong and Lim (1980)) for the NI-spread in a pooled time-series with two thresholds and three ranges - a low (i.e., <0 basis points), middle (i.e. between 0 and 5 basis 
points), and high (i.e., greater than 5 basis points) range of NI-spreads. ${ }^{12}$ If temporary price pressure is important for explaining NI-spreads, then it should be the case that shocks to the NIspread mean-revert in flight to quality episodes. Figure 4 presents the impulse response functions for the three thresholds. Of particular interest, shocks to NI-spreads in the low and high range of NI-spreads, that is, when credit quality is low and high respectively, are temporary and take around 16 weeks to completely disappear. Moreover, a significant portion of the shock has dissipated by the sixth week. In contrast, shocks in the middle range are white noise with no staying power. Figure 4 is broadly consistent with the notion that, during extreme periods of NI-spreads, there are price pressure episodes in which it takes a while for NI-spreads to revert to "normal" levels.

Note that for NI-spreads to behave contrary to the standard liquidity theory require temporary price pressure of the newly issued bond. The existence of this pressure requires (i) limits to arbitrage, and (ii) buying or selling pressure. With respect to the former, we argued in Section III that shorting difficulties for older bonds imply some limits to arbitrage. With respect to the latter, if bonds are in fixed supply, it is well-known that it is not straightforward to determine the trading direction (i.e., "pressure") underlying the transaction. In this subsection, we measure net trading flows using State Street Associates' dataset on the aggregated activities of institutional investors in terms of their net flows into and out of sovereign government bonds as a proxy for buying and selling pressure (e.g., Froot, O’Connell and Seasholes (2001) and Froot, Bhargava, Cuipa and Arabadjis (2014)).

With respect to the State Street data, State Street Corporation is one of the largest global custodians, with $\$ 25.7$ trillion of assets under custody, capturing 15\% of the global market (as of June 30, 2013). State Street argues that these assets represent a homogenous group of investors, socalled "real money", which are made up of primarily large global institutional investors, including mutual funds, pensions, foundations and endowments. Of some note, State Street's clients generally do not include corporations, retail investors, hedge funds or central banks. State Street takes each security-level transaction by the institutional investor and anonymously aggregates these transactions. For our purposes, each transaction in a country's sovereign government bonds are calculated as the difference in dollar value of buys minus sells at a given time t. State Street then

\footnotetext{
${ }^{12}$ We experimented with TAR(p) models up to order 4. All the results with respect to the impulse response function of shocks to NI-spreads are qualitatively similar, so we just show the results using a TAR(1).
} 
takes a 5-day exponential average of these net flows and converts these flows into a percentile based on the last five years of data. The sample starts in November 2005.

Table 10 documents the contemporaneous correlation pattern between the change in the cross-sectionally demeaned CDS premium, i.e., $\Delta\left(C D S_{i t}-\frac{1}{N} \sum_{i}^{N} C D S_{i t}\right)$, and net flows of sovereign government bonds for the 10 developed countries from November 2005-2015 (averaged over coincident periods, including 1, 2, 3 and 6 months). Consistent with the price pressure story, the correlation of changes in the flight to quality factor are negatively correlated with investor net flows for all 10 of the countries. In other words, when the credit quality of a country worsens, there is an increase in net flows out of that countries' sovereign bonds. Moreover, the magnitude of the correlation tends to increase with the horizon, consistent with noise in the net flows data. That said, many of the correlations are quite small in magnitude, the exceptions being Belgium $(-0.10,-0.22$, and -0.21$)$, Spain $(-0.20,-0.29$ and -0.44$)$, Italy $(-0.24,-0.37$ and -0.51$)$ and the Netherlands $(-0.17$, -0.34 and -0.34 ) at the monthly, quarterly and semi-annual horizon respectively. Three of these four countries suffered large negative shocks to their CDS premiums during the Euro crisis and exhibited negative NI-spreads during this same period. It is interesting to note that the correlation pattern is between investor flows and CDS spreads and does not involve the relative pricing of likewise bonds per se.

It is an empirical question of course who in this case is initiating the trades and potentially causing price pressure. Using State Street's measure of net flows, it is possible to partially answer this question. Since net flows are a measure of change in sovereign bonds holdings over a five-day period, in order to capture a level effect, we integrate over a sovereign bond's net flows using the prior and post 6 weeks around a given time period, yielding a quarterly average of net flows at any point in time. Moreover, since these net flows are relative to a five-year history, we convert all the variables - NI spreads and CDS relative quality - similarly against past 5-year values. We then reinvestigate regression equation (1) of NI spreads on the measure of net flows, alongside the common liquidity factor and the CDS quality factor. These results are reported in Table 11A.

Columns 1-2 of Table 11A document the regression equation (1) of NI spreads relative to their 5-year history on integrated net flows of the country's sovereign bonds. Note that the sample size is smaller than that of, for example, Table 6 due to the availability of the State Street data starting only in November 2005. As predicted by the price pressure story, NI spreads load 
positively on net flows with t-statistics above 2. In other words, the NI spread is higher (lower) for countries with higher (lower) net flows into their sovereign bonds. The liquidity premium increases (decreases) as the marginal investor buys (sells) the bonds. Under the price pressure explanation, this is expected as the investor chooses to transact in the more liquid, newly issue bond first.

As a point of reference, Columns 3-4 of Table 11A document the usual regression equation using the CDS quality variable relative to its 5-year history. Even though the sample size is different than that of Table 6, the results are very similar to those previously; specifically, the coefficient is of similar magnitude, negative and statistically significant. When integrated net flows are added to the regression (in columns 5 and 6), the coefficient on net flows only marginally changes and is again statistically significant. This is arguably to be expected as we argue that CDS relative quality and net flows are different ways of capturing the same price pressure phenomenon. Furthermore, when the common liquidity factor is added to the regression (in columns 7 and 8), the results are also similar to the earlier table. All the coefficients on common liquidity are positive (with 7 of the 9 countries being significant), and the coefficients on CDS relative quality and net flows remain significant and of similar magnitude.

In order to link the regression results of Table 11A to those of Table 10, Table 11B reports regression results for the CDS relative quality variable from Table 11A on the integrated net flows and contemporaneous net flow variable of sovereign bonds from the State Street data. The coefficients are both negative, with respectively one being borderline statistically significant and the other with a t-statistic above 2 . Therefore, consistent with the negative correlation between net flows and CDS changes documented in Table 10, Table 11B also shows that a transformed version of these variables is also negatively related. Combining Tables $11 \mathrm{~B}$ and 11A together implies that lower quality countries have higher net outflows and ceteris paribus tighter NI spreads. These tighter spreads, i.e., lower liquidity premiums, are consistent with selling pressure on the liquid, newly issued bonds.

\section{Conclusion}

What drives the liquidity of sovereign bonds? Current thinking is that government bonds with almost identical cash flows can trade at different prices due to liquidity, and these differences extenuate during global crises. In contrast, according to results presented in this paper, there is 
evidence of not only a common liquidity factor, but also a country-specific flight to quality factor. Global crises can actually lead to the opposite impact due to liquidity. In particular, when a country suffers credit deterioration and/or a flight to quality, bond spreads tighten and can actually go negative. In other words, the liquid bonds become cheaper, not more expensive, than their less liquid counterparts. We offer an explanation based on temporary price pressure and provide empirical support using data on net flows of investors in sovereign bonds and of mean reversion in shocks to bond spreads. Of some interest, we are able to reconcile the differential behavior of bond spreads of the U.S. and Germany versus Spain and Italy during the Eurozone crisis period.

An interesting question is whether the findings of this paper are endemic to the government bond market or can be applied elsewhere in capital markets. For example, consider the capital structure of a firm that includes many bonds of similar credit risk, yet of possible different liquidity. When a corporation suffers financial distress (or, more broadly, a credit crisis occurs), what happens to the yield spreads between different bonds of the firm? The current view is that the spread would widen as the illiquid bond falls in value; the results in this paper suggest the opposite. Pulvino and Stafford (2013) provide an analysis of the financial crisis and the CDS-bond basis, which suggests that corporates and governments may be different. We leave this topic, and related ones on an asset quality-based liquidity factor, to future research. 


\section{References}

Amihud, Yakov and Haim Mendelson, 1986, Asset pricing and the bid-ask spread, Journal of Financial Economics 17, 223-249.

Amihud, Yakov and Haim Mendelson, 1991, Liquidity, maturity and the yields on U.S. government securities, Journal of Finance 46, 1411-1426.

Amihud, Yakov, Haim Mendelson, and Lasse H. Pedersen, 2005, Liquidity and Asset Pricing, Foundations and Trends in Finance 1, 269-364.

Andritzky, Jochen A., 2012, Government Bonds and Their Investors: What Are the Effects and Do They Matter?, IMF working paper 12/158.

Arslanalp, Serkan and Tigran Poghosyyan, 2014, Foreign Investor Flows and Sovereign Bond Yields in Advanced Economies, IMF working paper 14/27.

Arslanalp, Serkan and Takahiro Tsuda, 2014, Tracking Global Demand for Advanced Economy Sovereign Debt, IMF Economic Review 62: 430-464.

Bai, J., Julliard, C., and Yuan, K., 2012, Eurozone Sovereign Bond Crisis: Liquidity or Fundamental Contagion, Working Paper.

Banerjee, Snehal, and Jeremy Graveline, 2013, The Cost of Short-Selling Liquid Securities, Journal of Finance, 68 (2): 637-664.

Beber, Alessandro, Michael W. Brandt and Kenneth A. Kavajecz

, 2009, Flight-to-Quality or Flight-to-Liquidity? Evidence from the Euro-Area Bond Market. The Review of Financial Studies 22(3), 925-957.

Beirne, J. and M. Fratzscher (2013). The Pricing of Sovereign Risk and Contagion During the European Sovereign Debt Crisis. Journal of International Money and Finance 34, 60-82.

Boudoukh, Jacob, and Robert F. Whitelaw, 1993, Liquidity as a choice variable: A lesson from the Japanese government bond market, The Review of Financial Studies 6, 265-292.

Buraschi, Andrea, Emrah Sener, and Murat Meng"ut"urk, 2010, The Dynamics of Limits to Arbitrage: An Empirical Investigation of the Sovereign Bond Market, Working paper, Imperial College.

Cornell, Bradford, and Alan C. Shapiro, 1990, The Mispricing of U.S. Treasury Bonds: A Case Study, Review of Financial Studies 2, 297-310.

D’Agostino, A. and M. Ehrmann (2014). The Pricing of G7 Sovereign Bond Spreads - The Times, They are A-Changin. Journal of Banking and Finance 14, 155-176. 
D'Amico, Stefania and Thomas B. King, 2013, "Flow and Stock Effects of Large-Scale Treasury Purchases: Evidence on the Importance of Local Supply," Journal of Financial Economics, 108, 425-448.

Darbha, M. and Dufour, A., 2015, Euro Area Government Bond Market liquidity, Working Paper, University of Reading.

De Jong, Frank and Joost Driessen, 2005, Liquidity risk premia in corporate bond markets, Working Paper, University of Amsterdam.

Duffie, Darrell, Nicolae Garleanu and Lasse H. Pedersen, 2002, Securities lending, shorting, and pricing, Journal of Financial Economics 66, 307-339.

Dunne, P. G., M. J. Moore, and R. Portes. 2003. Defining Benchmark Status: An Application Using Euro-area Bonds. Working Paper 9087, NBER.

Edwin J. Elton and T. Clifton Green, 1998, Tax and liquidity effects in pricing of government bonds, Journal of Finance 53, 1533-62

Ericsson, Jan, and Olivier Renault. 2006. Liquidity and Credit Risk. Journal of Finance 61:2219-50.

Favero, Carlo, Marco Pagano, and Ernst-Ludwig Von Thadden. 2010. How Does Liquidity Affect Government Bond Yields? Journal of Financial and Quantitative Analysis 45 (1): 107134.

Feldhutter, Peter. 2012. The same bond at different prices: identifying search frictions and selling pressures." Review of Financial Studies 25:1155-1206.

Fisher, Lawrence, and Roman L. Weil. 1971. "Coping with the risk of interest-rate fluctuations: returns to bondholders from naive and optimal strategies." The Journal of Business 44 (4): 408431.

Fleming, Michael J., 2002, Are Larger Issues More Liquid? Evidence from Bill Reopenings, Journal of Money, Credit and Banking 34 (3): 707-735.

Fleming, Michael J., 2003, Measuring Treasury Market Liquidity, Federal Reserve Bank of New York Economic Policy Review (September), 83-108.

Froot, Kenneth A., Bhargava, Rajeev, Cuipa, Edward S. and John S. Arabadjis, 2014, MultiAsset Sentiment and Institutional Investor Behavior: A Cross-Asset Perspective, Journal of Portfolio Management, 144-156.

Froot, Kenneth A., Paul G.J. O'Connell and Mark S. Seasholes, 2001, The Portfolio Flows of International Investors, Journal of Financial Economics 59 (2): 151-193. 
Garleanu, Nicolae, Lasse H. Pedersen, and Allen Poteshman, 2004, Demand-based option pricing, Working paper, The Wharton School.

Goldreich, David, Bernd Hanke and Purnendu Nath, 2005, The price of future liquidity: Timevarying liquidity in the U.S. Treasury market, Review of Finance 9:1-32.

Goyenko, Ruslan, Avanidhar Subrahmanyam and Andrey Ukhov, 2011, The term structure of bond market liquidity and its implications for expected bond returns. Journal of Financial and Quantitative Analysis, 46(1), 111-139.

Graveline, Jeremy J. and Matthew R. McBrady, 2011, Whom Makes On-the-run Treasuries Special?, Journal of Financial Intermediation 20 (4): 620-632.

Greenwood, Robin, and Dimitri Vayanos, 2010, "Price Pressure in the Government Bond Market," American Economic Review, Papers and Proceedings, 585-590.

Greenwood, Robin, Hanson, Samuel G., and Gordon Y. Liao, 2016, “Asset Price Dynamics in Partially Segmented Markets", working paper, Harvard University.

Grossman, Sanford J. and Merton H. Miller, 1988, Liquidity and market structure, Journal of Finance 43, 617-633.

Harrison, J. Michael and David M. Kreps, 1978, Speculative Investor Behavior in a Stock Market with Heterogenous Expectations, The Quarterly Journal of Economics, 92 (2): 323-336.

Hong, Harrison and Jeremy Stein, 2003, Differences of Opinion, Short-Sales Constraints, and Market Crashes, The Review of Financial Studies, 16 (2): 487-525.

Jordan, Bradford, Randy Jorgensen, and David Kuipers, 2000, The Relative Pricing of U.S. Treasury STRIPS, Journal of Financial Economics 56, 89-123.

Kamara, Avraham, 1994, Liquidity, taxes, and short-term treasury yields, Journal of Financial and Quantitative Analysis 29, 403-416.

Kliesen, Kevin L. and Dougla C. Smith, 2010, Measuring Financial Market Stress, Economic Synopses, St. Louis Federal Reserve Bank of St. Louis, 1-2.

Krishnamurthi, Arvind, 2002, The bond/old-bond spread, Journal of financial Economics 66, 463-506.

Longstaff, Francis A., 2004, The flight-to-liquidity premium in U.S. Treasury bond prices, Journal of Business 77 (3): 511-526.

Longstaff, Francis A., Sanjay Mithal, and Eric Neis. 2005. Corporate Yield Spreads: Default Risk or Liquidity? New Evidence from the Credit-Default Swap Market. Journal of Finance 55:2213-53. 
Lou, Dong, Hongjun Yan and Zinfan Zhang, 2013, Anticipated and Repeated Shocks in Liquid Markets, Review of Financial Studies 26 (8): 1891-1912.

Ofek, Eli and Matthew Richardson, 2003, DotCom Mania: The Rise and Fall of Internet Stock Prices, The Journal of Finance, 58 (3): 1113-1138.

Pasquariello, Paolo and Clara Vega, 2009, The On-the-run Liquidity Phenomenon, Journal of Financial Economics 92 (1): 1-24.

Pelizzon, Loriana, Subrahmanyam, Marti G., Tomio, Davide and Jun Uno, 2015, Sovereign Credit Risk, Liquidity, and ECB Intervention: Deus ex Machina?, forthcoming Journal of Financial Economics.

Schwartz, Kyra, 2010, Mind the Gap: Disentangling Credit and Liquidity in Risk Spreads, working paper, The Wharton School, University of Pennsylvania.

Strebulaev, Ilya, A. 2002, Many faces of liquidity and asset pricing: Evidence from the U.S. Treasury securities market. Working paper, Stanford University.

Vayanos, Dimitri, 2004, Flight to quality, flight to liquidity and the pricing of risk, Working paper, LSE.

Vayanos, Dimitri, and Pierre-Oliver Weill, 2008, A Search-Based Theory of the On-the-Run Phenomenon, Journal of Finance 63, 1361-1398.

Vayanos, Dimitri, and Jean-Luc Vila. 2009. A preferred-habitat model of the term structure of interest rates." Working paper.

Warga, Arthur, 1992, Bond returns, liquidity, and missing data, Journal of Financial and Quantitative Analysis 27, 605-617. 


\section{Table 1 - Issuance Analysis}

Table 1 documents properties of the issuance cycle for the 10-year newly issued bond across 10 developed countries over the period 1998-2015. The represented countries are BE (Belgium), CA (Canada), DE (Germany), ES (Spain), FR (France), GB (United Kingdom), IT (Italy), JP (Japan), NL (Netherlands) and US (United States). Table 1A documents properties of the issuance cycle for the 10year bond, while Table $1 \mathrm{~B}$ documents the properties of the reissuance cycle.

Table 1A 10Yr Point Issuances

\begin{tabular}{lcccccccccc}
\hline & BE & CA & DE & ES & FR & GB & IT & JP & NL & US \\
\hline Total Number & 19 & 19 & 44 & 25 & 41 & 27 & 33 & 144 & 20 & 81 \\
Avg. Issuance Cycle & 364 & 363 & 152 & 281 & 164 & 253 & 205 & 45 & 369 & 104 \\
Min Issuance Cycle & 312 & 272 & 70 & 65 & 8 & 8 & 9 & 6 & 224 & 59 \\
Max Issuance Cycle & 413 & 546 & 224 & 497 & 270 & 1030 & 334 & 94 & 455 & 186 \\
STD Issuance Cycle & 19 & 57 & 40 & 131 & 72 & 263 & 72 & 22 & 51 & 33 \\
First Date & Jan-98 & Jan-98 & Jan-98 & Jan-98 & Jan-98 & Jan-98 & Jan-98 & Jan-98 & Jan-98 & Jan-93 \\
\hline
\end{tabular}

Table 1B \% of Total Amount Issued (10Yr, 1998:01 - 2015:06)

\begin{tabular}{lcccccccccc}
\hline & BE & CA & DE & ES & FR & GB & IT & JP & NL & US \\
\hline First Issuance & $33 \%$ & $28 \%$ & $36 \%$ & $13 \%$ & $20 \%$ & $10 \%$ & $27 \%$ & $92 \%$ & $39 \%$ & $47 \%$ \\
Within 30D & $35 \%$ & $29 \%$ & $45 \%$ & $29 \%$ & $27 \%$ & $14 \%$ & $39 \%$ & $94 \%$ & $40 \%$ & $74 \%$ \\
Within 91D & $48 \%$ & $42 \%$ & $90 \%$ & $57 \%$ & $44 \%$ & $25 \%$ & $61 \%$ & $94 \%$ & $54 \%$ & $99 \%$ \\
Within 183D & $62 \%$ & $62 \%$ & $99 \%$ & $86 \%$ & $65 \%$ & $43 \%$ & $88 \%$ & $94 \%$ & $73 \%$ & $99 \%$ \\
Within 274D & $79 \%$ & $85 \%$ & $100 \%$ & $90 \%$ & $71 \%$ & $56 \%$ & $93 \%$ & $96 \%$ & $82 \%$ & $99 \%$ \\
Within 365D & $89 \%$ & $100 \%$ & $100 \%$ & $92 \%$ & $72 \%$ & $63 \%$ & $93 \%$ & $96 \%$ & $85 \%$ & $99 \%$ \\
Beyond 365D & $11 \%$ & $0 \%$ & $0 \%$ & $8 \%$ & $28 \%$ & $37 \%$ & $7 \%$ & $4 \%$ & $15 \%$ & $1 \%$ \\
\hline
\end{tabular}




\section{Table 2 - Bid-Ask Spread Analysis}

Table 2 summary statistics for the bid-ask spreads for the 10-year newly issued bond and average of two latest old bonds across 10 developed countries over the period October 2013-2015. The represented countries are BE (Belgium), CA (Canada), DE (Germany), ES (Spain), FR (France), GB (United Kingdom), IT (Italy), JP (Japan), NL (Netherlands) and US (United States).

\begin{tabular}{lccccc}
\hline & BE & CA & DE & ES & FR \\
\hline New bond average bid-ask spread (bps) & 0.96 & 0.84 & 0.43 & 1.52 & 0.72 \\
Old bond average bid-ask spread (bps) & 1.14 & 1.00 & 0.37 & 1.75 & 0.75 \\
Difference & -0.17 & -0.16 & 0.07 & -0.23 & -0.03 \\
& $(-1.23)$ & $(-2.67)$ & $(5.75)$ & $(-4.66)$ & $(-1.61)$ \\
\hline \% New bond with higher bid-ask spread & $41 \%$ & $31 \%$ & $60 \%$ & $26 \%$ & $34 \%$ \\
\% Old bond with higher bid-ask spread & $53 \%$ & $59 \%$ & $17 \%$ & $69 \%$ & $57 \%$ \\
Difference & $-12 \%$ & -0.28 & 0.43 & -0.43 & -0.23 \\
& $(-1.20)$ & $(-2.82)$ & $(5.10)$ & $(-4.63)$ & $(-2.36)$ \\
\hline \# of Obs & 91 & 91 & 91 & 91 & 91 \\
\hline & GB & IT & JP & NL & US \\
\hline New bond average bid-ask spread (bps) & 0.52 & 1.03 & 0.75 & 0.79 & 0.23 \\
Old bond average bid-ask spread (bps) & 0.55 & 1.21 & 0.74 & 0.82 & 0.28 \\
Difference & -0.03 & -0.18 & 0.01 & -0.03 & -0.05 \\
& $(-1.78)$ & $(-3.06)$ & $(0.20)$ & $(-2.55)$ & $(-4.43)$ \\
\hline \% New bond with higher bid-ask spread & $20 \%$ & $29 \%$ & $26 \%$ & $27 \%$ & $14 \%$ \\
\% Old bond with higher bid-ask spread & $53 \%$ & $69 \%$ & $33 \%$ & $47 \%$ & $80 \%$ \\
Difference & -0.33 & -0.41 & -0.07 & -0.20 & -0.66 \\
& $(-3.98)$ & $(-4.28)$ & $(-0.83)$ & $(-2.23)$ & $(-8.76)$ \\
\hline \# of Obs & 91 & 91 & 91 & 91 & 91 \\
\hline
\end{tabular}




\section{Table 3 - Yield Spreads}

Table 3A documents summary statistics for the spread between the latest issued and likewise newly issued 10-year bond across 10 developed countries over the period 1998-2015. The represented countries are BE (Belgium), CA (Canada), DE (Germany), ES (Spain), FR (France), GB (United Kingdom), IT (Italy), JP (Japan), NL (Netherlands) and US (United States). Table 3B reports pooled time-series regressions of the spread on a local measure of the term structure slope, as well as estimates of duration and convexity.

Table 3A Summary Statistics of Yield Spreads

\begin{tabular}{lcccccccccc}
\hline & BE & CA & DE & ES & FR & GB & IT & JP & NL & US \\
\hline \# of Obs & 912 & 912 & 912 & 912 & 912 & 912 & 912 & 912 & 912 & 1,173 \\
Average & -10.1 & -7.0 & -2.9 & -7.5 & -5.9 & -1.7 & -6.6 & -2.2 & -9.1 & 0.8 \\
Vol & 2.5 & 1.4 & 1.0 & 4.0 & 1.9 & 2.1 & 3.1 & 2.1 & 1.7 & 1.4 \\
Min & -43.2 & -24.0 & -10.4 & -58.1 & -22.8 & -36.3 & -41.9 & -19.7 & -22.1 & -16.9 \\
Max & 11.2 & 16.0 & 8.6 & 29.8 & 12.2 & 48.5 & 13.6 & 26.0 & 1.4 & 17.1 \\
5th \% & -25.4 & -15.1 & -7.1 & -18.8 & -12.9 & -19.7 & -19.5 & -7.3 & -19.3 & -4.7 \\
95th \% & -1.2 & 0.4 & 1.7 & -0.4 & -0.3 & 32.5 & 3.0 & 2.1 & -1.1 & 8.5 \\
\hline
\end{tabular}

Table 3B Yield Spread Explained by Other Variables

\begin{tabular}{lccccccc}
\hline & \multicolumn{3}{c}{ Level } & & \multicolumn{3}{c}{ Change } \\
\cline { 2 - 3 } \cline { 6 - 7 } Local Slope & 0.85 & & 0.89 & & 0.56 & & 0.57 \\
& $(11.18)$ & & $(15.38)$ & & $(8.17)$ & & $(8.04)$ \\
Duration & & -17.84 & -10.50 & & & -5.13 & -2.89 \\
& & $(-2.46)$ & $(-3.60)$ & & & $(-1.97)$ & $(-1.67)$ \\
Convexity & & 1.13 & 0.35 & & & 0.51 & 0.13 \\
& & $(2.64)$ & $(1.86)$ & & & $(2.44)$ & $(0.92)$ \\
r2 & $63 \%$ & $21 \%$ & $66 \%$ & & $21 \%$ & $1 \%$ & $21 \%$ \\
r2 net of FE & $59 \%$ & $6 \%$ & $59 \%$ & & $21 \%$ & $1 \%$ & $21 \%$ \\
\hline
\end{tabular}




\section{Table 4 - NI Spreads}

Table 4A documents summary statistics for the NI-spread (the difference of yields between a hypothetical bond priced by the older bond' curve minus its newly issued counterpart), i.e., NI - spread $=y^{h y p}-$ $y^{\text {actual }}=\frac{\text { price }^{\text {hyp }}-\text { price actual }}{\text { price }}$, for duration 10 -year bond across 10 developed countries over the period 1998-2015. The represented countries are BE (Belgium), CA (Canada), DE (Germany), ES (Spain), FR (France), GB (United Kingdom), IT (Italy), JP (Japan), NL (Netherlands) and US (United States). Table $4 \mathrm{~B}$ reports pooled time-series regressions of the spread on a local measure of the term structure slope, as well as estimates of duration and convexity.

Table 4A Summary Statistics of NI Spreads

\begin{tabular}{lcccccccccc}
\hline & BE & CA & DE & ES & FR & GB & IT & JP & NL & US \\
\hline \# of Obs & 912 & 912 & 912 & 912 & 912 & 912 & 912 & 912 & 912 & 1,173 \\
Average & 0.4 & 3.8 & 2.1 & 0.8 & 0.6 & 0.9 & 0.2 & -0.4 & 3.1 & 4.8 \\
Vol & 2.3 & 1.9 & 1.0 & 3.3 & 1.5 & 1.8 & 2.6 & 1.9 & 1.7 & 1.5 \\
Min & -22.8 & -13.2 & -4.0 & -32.5 & -11.6 & -16.8 & -29.9 & -27.1 & -7.2 & -11.0 \\
Max & 32.2 & 19.6 & 10.0 & 32.3 & 12.1 & 14.1 & 26.8 & 9.8 & 22.3 & 18.7 \\
5th \% & -8.3 & -2.7 & -0.5 & -8.5 & -3.0 & -4.1 & -13.4 & -3.6 & -1.5 & 0.4 \\
95th \% & 7.4 & 12.9 & 5.8 & 8.0 & 5.9 & 9.1 & 11.9 & 1.9 & 9.6 & 13.0 \\
\hline rho(1) & 0.91 & 0.93 & 0.88 & 0.84 & 0.83 & 0.90 & 0.94 & 0.75 & 0.91 & 0.94 \\
rho(4) & 0.73 & 0.78 & 0.69 & 0.68 & 0.67 & 0.71 & 0.87 & 0.06 & 0.83 & 0.79 \\
rho(12) & 0.55 & 0.50 & 0.43 & 0.32 & 0.39 & 0.59 & 0.70 & 0.00 & 0.72 & 0.55 \\
rho(24) & 0.45 & 0.25 & 0.36 & 0.14 & 0.13 & 0.47 & 0.64 & 0.02 & 0.57 & 0.51 \\
\hline
\end{tabular}

Table 4B NI Spread Explained by Other Variables

\begin{tabular}{lccccccc}
\hline & \multicolumn{3}{c}{ Level } & & \multicolumn{3}{c}{ Change } \\
\cline { 2 - 3 } \cline { 6 - 8 } Local Slope & -0.14 & & -0.10 & & -0.38 & & -0.37 \\
& $(-1.90)$ & & $(-1.82)$ & & $(-7.95)$ & & $(-7.27)$ \\
Duration & & -7.70 & -8.53 & & & -0.36 & -1.81 \\
& & $(-2.86)$ & $(-3.05)$ & & & $(-0.22)$ & $(-1.11)$ \\
Convexity & & 0.16 & 0.24 & & & -0.19 & 0.06 \\
& & $(0.87)$ & $(1.34)$ & & & $(-1.46)$ & $(0.46)$ \\
r2 & $16 \%$ & $21 \%$ & $23 \%$ & & $12 \%$ & $2 \%$ & $12 \%$ \\
r2 net of FE & $3 \%$ & $1 \%$ & $4 \%$ & & $12 \%$ & $2 \%$ & $12 \%$ \\
\hline
\end{tabular}




\section{Table 5 - Correlation Between NI Spreads}

Table 5A documents the correlation matrix for the NI-spread (the difference of yields between a hypothetical bond priced by the older bonds' curve minus its newly issued counterpart), i.e. NI spread $=y^{\text {hyp }}-y^{\text {actual }}=\frac{\text { price }^{\text {hyp }}-\text { price }}{\text { prictual }}$, for the 10 -year bond across 10 developed countries over the period 1998-2015. The represented countries are BE (Belgium), CA (Canada), DE (Germany), ES (Spain), FR (France), GB (United Kingdom), IT (Italy), JP (Japan), NL (Netherlands) and US (United States). Table 5B documents the first three principal components underlying the OTR-spread data over the sample period.

Table 5A Correlation Matrix of Level of 10 Yr NI Spreads

\begin{tabular}{|c|c|c|c|c|c|c|c|c|c|c|}
\hline & $\mathrm{BE}$ & $\mathrm{CA}$ & DE & ES & FR & GB & IT & JP & NL & US \\
\hline $\mathrm{BE}$ & 1.00 & -0.08 & -0.23 & 0.26 & 0.36 & 0.28 & 0.53 & -0.19 & 0.22 & 0.35 \\
\hline CA & & 1.00 & 0.29 & 0.02 & 0.07 & 0.03 & -0.13 & 0.04 & 0.15 & 0.08 \\
\hline $\mathrm{DE}$ & & & 1.00 & -0.10 & -0.07 & -0.04 & -0.25 & -0.03 & 0.04 & 0.01 \\
\hline ES & & & & 1.00 & 0.17 & 0.04 & 0.47 & -0.09 & 0.22 & 0.22 \\
\hline FR & & & & & 1.00 & 0.20 & 0.38 & -0.15 & 0.39 & 0.25 \\
\hline GB & & & & & & 1.00 & 0.42 & -0.16 & 0.37 & 0.53 \\
\hline IT & & & & & & & 1.00 & -0.15 & 0.48 & 0.38 \\
\hline JP & & & & & & & & 1.00 & -0.24 & -0.26 \\
\hline NL & & & & & & & & & 1.00 & 0.35 \\
\hline US & & & & & & & & & & 1.00 \\
\hline
\end{tabular}

Table 5B Principal Component Analysis for 10 Yr NI Spreads

\begin{tabular}{ccccccccccc}
\hline$\%$ Var & BE & CA & DE & ES & FR & GB & IT & JP & NL & US \\
\hline $43.6 \%$ & -0.40 & 0.04 & 0.05 & -0.36 & -0.12 & -0.21 & -0.74 & 0.07 & -0.22 & -0.24 \\
$12.9 \%$ & 0.12 & 0.41 & 0.08 & -0.63 & 0.09 & 0.44 & -0.07 & -0.08 & 0.23 & 0.37 \\
$12.6 \%$ & 0.28 & -0.75 & -0.13 & -0.54 & -0.02 & 0.06 & 0.13 & -0.01 & -0.16 & -0.10 \\
\hline
\end{tabular}




\section{Table 6 - Common Factor and Price Pressure}

Table 6 documents the regression of the NI-spread (the difference of yields between a hypothetical 10year bond priced by the older bonds' curve minus its newly issued counterpart), i.e. $N I-$ spread $=$ $y^{\text {hyp }}-y^{\text {actual }}=\frac{\text { price }^{\text {hyp }} \text {-price }}{\text { prictual }}$, pryp $_{\text {duration }}$, on measures of a common liquidity factor and a flight to quality factor across 10 developed countries over the period 1998-2015. Specifically, we run variants of the following regression model:

$$
\mathrm{NI}_{i t}=\alpha+\beta_{i} F_{t}+\gamma\left(C D S_{i t}-\frac{1}{N} \sum_{i=1}^{N} C D S_{i t}\right)+\varepsilon_{i t}
$$

where we model a common component to liquidity, $F_{t}$, by taking a median of the NI-spreads, $F_{t}=$ median $\left(\left\{N I_{i t}\right\}_{i}\right)$, and we choose $\left(C D S_{i t}-\frac{1}{N} \sum_{i}^{N} C D S_{i t}\right)$ as a measure of the relative credit quality across the $N$ countries.

\begin{tabular}{|c|c|c|c|c|c|c|c|c|}
\hline & 1 & 2 & 3 & 4 & 5 & 6 & 7 & 8 \\
\hline Intercept & $\begin{array}{c}0.15 \\
(0.41) \\
\end{array}$ & $\mathrm{FE}$ & $\begin{array}{c}0.61 \\
(2.05) \\
\end{array}$ & $\mathrm{FE}$ & $\begin{array}{c}1.66 \\
(4.98) \\
\end{array}$ & $\mathrm{FE}$ & $\begin{array}{c}0.15 \\
(0.49) \\
\end{array}$ & $\mathrm{FE}$ \\
\hline $\mathrm{BE}$ & $\begin{array}{c}0.94 \\
(6.52)\end{array}$ & $\begin{array}{c}1.41 \\
(4.92)\end{array}$ & & & & & $\begin{array}{c}0.95 \\
(6.70)\end{array}$ & $\begin{array}{c}1.38 \\
(5.11)\end{array}$ \\
\hline CA & $\begin{array}{c}1.17 \\
(6.94)\end{array}$ & $\begin{array}{c}0.50 \\
(1.87)\end{array}$ & & & & & $\begin{array}{c}1.10 \\
(8.34)\end{array}$ & $\begin{array}{c}0.57 \\
(2.26)\end{array}$ \\
\hline $\mathrm{DE}$ & $\begin{array}{c}0.46 \\
(3.12)\end{array}$ & $\begin{array}{c}0.00 \\
(0.00)\end{array}$ & & & & & $\begin{array}{c}0.40 \\
(3.20)\end{array}$ & $\begin{array}{c}0.08 \\
(0.51)\end{array}$ \\
\hline ES & $\begin{array}{c}0.83 \\
(5.46)\end{array}$ & $\begin{array}{c}1.08 \\
(5.06)\end{array}$ & & & & & $\begin{array}{c}0.97 \\
(6.40)\end{array}$ & $\begin{array}{c}0.89 \\
(5.43)\end{array}$ \\
\hline FR & $\begin{array}{c}0.55 \\
(3.63)\end{array}$ & $\begin{array}{c}0.69 \\
(4.87)\end{array}$ & & & & & $\begin{array}{c}0.54 \\
(3.71)\end{array}$ & $\begin{array}{c}0.71 \\
(4.95)\end{array}$ \\
\hline GB & $\begin{array}{c}0.86 \\
(4.20)\end{array}$ & $\begin{array}{c}1.08 \\
(6.71)\end{array}$ & & & & & $\begin{array}{c}0.80 \\
(3.80)\end{array}$ & $\begin{array}{c}1.11 \\
(6.55)\end{array}$ \\
\hline IT & $\begin{array}{c}1.51 \\
(6.09)\end{array}$ & $\begin{array}{c}2.38 \\
(8.52)\end{array}$ & & & & & $\begin{array}{c}1.66 \\
(7.89)\end{array}$ & $\begin{array}{c}2.19 \\
(8.88)\end{array}$ \\
\hline JP & $\begin{array}{c}-0.30 \\
(-2.26)\end{array}$ & $\begin{array}{c}-0.26 \\
(-1.92)\end{array}$ & & & & & $\begin{array}{c}-0.26 \\
(-2.06)\end{array}$ & $\begin{array}{c}-0.19 \\
(-1.33)\end{array}$ \\
\hline NL & $\begin{array}{c}1.54 \\
(8.41)\end{array}$ & $\begin{array}{c}1.35 \\
(6.48)\end{array}$ & & & & & $\begin{array}{c}1.50 \\
(7.80)\end{array}$ & $\begin{array}{c}1.41 \\
(6.74)\end{array}$ \\
\hline US & $\begin{array}{c}1.91 \\
(6.67) \\
\end{array}$ & $\begin{array}{c}1.25 \\
(5.66) \\
\end{array}$ & & & & & $\begin{array}{c}1.82 \\
(6.51) \\
\end{array}$ & $\begin{array}{c}1.33 \\
(5.29) \\
\end{array}$ \\
\hline CDS_i & & & $\begin{array}{c}-0.03 \\
(-3.96)\end{array}$ & $\begin{array}{c}-0.02 \\
(-3.65)\end{array}$ & $\begin{array}{c}-0.03 \\
(-3.90)\end{array}$ & $\begin{array}{c}-0.02 \\
(-2.90)\end{array}$ & $\begin{array}{c}-0.03 \\
(-4.00)\end{array}$ & $\begin{array}{c}-0.02 \\
(-3.06)\end{array}$ \\
\hline $\mathrm{r} 2$ & $27 \%$ & $38 \%$ & $13 \%$ & $20 \%$ & $8 \%$ & $16 \%$ & $35 \%$ & $41 \%$ \\
\hline \# of Obs & 9120 & 9120 & 6523 & 6523 & 9120 & 9120 & 9120 & 9120 \\
\hline
\end{tabular}




\section{Table 7 - Subsample Analysis}

Table 7 documents the regression of the NI-spread (the difference of yields between a hypothetical 10year bond priced by the older bonds' curve minus its newly issued counterpart), i.e., NI - spread =

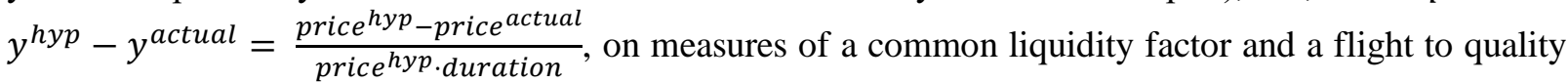
factor across 10 developed countries over two subperiods, pre-2008 and post 2008 over the sample period 1998-2015. Specifically, we run variants of the following regression model:

$$
\mathrm{NI}_{i t}=\alpha+\beta_{i} F_{t}+\gamma\left(C D S_{i t}-\frac{1}{N} \sum_{i=1}^{N} C D S_{i t}\right)+\varepsilon_{i t}
$$

where we model a common component to liquidity, $F_{t}$, by taking a median of the NI-spreads, $F_{t}=\operatorname{median}\left(\left\{N I_{i t}\right\}_{i}\right)$, and we choose $\left(C D S_{i t}-\frac{1}{N} \sum_{i}^{N} C D S_{i t}\right)$ as a measure of the relative credit quality across the $N$ countries.

Table 7A Pre 2008: Common Factor and Price Pressure

\begin{tabular}{|c|c|c|c|c|c|c|c|c|}
\hline & 1 & 2 & 3 & 4 & 5 & 6 & 7 & 8 \\
\hline Intercept & $\begin{array}{c}0.44 \\
(1.82) \\
\end{array}$ & $\mathrm{FE}$ & $\begin{array}{c}0.80 \\
(3.65) \\
\end{array}$ & $\mathrm{FE}$ & $\begin{array}{c}2.53 \\
(6.61) \\
\end{array}$ & FE & $\begin{array}{c}0.44 \\
(1.96) \\
\end{array}$ & FE \\
\hline $\mathrm{BE}$ & $\begin{array}{c}0.87 \\
(6.94)\end{array}$ & $\begin{array}{c}0.88 \\
(6.79)\end{array}$ & & & & & $\begin{array}{c}0.83 \\
(6.60)\end{array}$ & $\begin{array}{c}0.88 \\
(6.78)\end{array}$ \\
\hline $\mathrm{CA}$ & $\begin{array}{c}0.99 \\
(9.78)\end{array}$ & $\begin{array}{c}0.81 \\
(5.77)\end{array}$ & & & & & $\begin{array}{c}0.90 \\
(8.83)\end{array}$ & $\begin{array}{c}0.80 \\
(5.76)\end{array}$ \\
\hline $\mathrm{DE}$ & $\begin{array}{c}0.37 \\
(3.07)\end{array}$ & $\begin{array}{c}0.23 \\
(2.21)\end{array}$ & & & & & $\begin{array}{c}0.34 \\
(2.79)\end{array}$ & $\begin{array}{c}0.22 \\
(2.20)\end{array}$ \\
\hline ES & $\begin{array}{c}0.76 \\
(5.29)\end{array}$ & $\begin{array}{c}1.08 \\
(10.26)\end{array}$ & & & & & $\begin{array}{c}0.73 \\
(5.19)\end{array}$ & $\begin{array}{c}1.08 \\
(10.04)\end{array}$ \\
\hline FR & $\begin{array}{c}0.45 \\
(2.85)\end{array}$ & $\begin{array}{c}0.66 \\
(3.65)\end{array}$ & & & & & $\begin{array}{c}0.42 \\
(2.54)\end{array}$ & $\begin{array}{c}0.66 \\
(3.64)\end{array}$ \\
\hline GB & $\begin{array}{c}0.90 \\
(4.86)\end{array}$ & $\begin{array}{c}0.97 \\
(5.09)\end{array}$ & & & & & $\begin{array}{c}0.82 \\
(4.50)\end{array}$ & $\begin{array}{c}0.96 \\
(5.11)\end{array}$ \\
\hline IT & $\begin{array}{c}1.51 \\
(6.87)\end{array}$ & $\begin{array}{c}1.85 \\
(10.84)\end{array}$ & & & & & $\begin{array}{c}1.57 \\
(7.68)\end{array}$ & $\begin{array}{c}1.84 \\
(10.36)\end{array}$ \\
\hline JP & $\begin{array}{c}-0.43 \\
(-4.66)\end{array}$ & $\begin{array}{c}-0.32 \\
(-2.29)\end{array}$ & & & & & $\begin{array}{c}-0.08 \\
(-0.37)\end{array}$ & $\begin{array}{c}-0.29 \\
(-1.66)\end{array}$ \\
\hline NL & $\begin{array}{c}1.57 \\
(9.50)\end{array}$ & $\begin{array}{c}1.49 \\
(7.95)\end{array}$ & & & & & $\begin{array}{c}1.57 \\
(9.14)\end{array}$ & $\begin{array}{c}1.49 \\
(7.94)\end{array}$ \\
\hline US & $\begin{array}{c}1.97 \\
(6.55)\end{array}$ & $\begin{array}{c}1.33 \\
(6.98)\end{array}$ & & & & & $\begin{array}{c}1.86 \\
(6.67)\end{array}$ & $\begin{array}{c}1.33 \\
(7.01)\end{array}$ \\
\hline CDS_i & & & $\begin{array}{c}-0.19 \\
(-3.14)\end{array}$ & $\begin{array}{c}-0.15 \\
(-2.29)\end{array}$ & $\begin{array}{c}-0.33 \\
(-4.19)\end{array}$ & $\begin{array}{c}-0.25 \\
(-2.10)\end{array}$ & $\begin{array}{c}-0.14 \\
(-1.98)\end{array}$ & $\begin{array}{c}-0.02 \\
(-0.38)\end{array}$ \\
\hline $\mathrm{r} 2$ & $51 \%$ & $56 \%$ & $9 \%$ & $22 \%$ & $10 \%$ & $22 \%$ & $52 \%$ & $56 \%$ \\
\hline \# of Obs & 5210 & 5210 & 2613 & 2613 & 5210 & 5210 & 5210 & 5210 \\
\hline
\end{tabular}


Table 7B Post 2008: Common Factor and Price Pressure

\begin{tabular}{|c|c|c|c|c|c|c|c|c|}
\hline & 1 & 2 & 3 & 4 & 5 & 6 & 7 & 8 \\
\hline Intercept & $\begin{array}{c}-0.05 \\
(-0.08)\end{array}$ & FE & $\begin{array}{c}0.49 \\
(1.06)\end{array}$ & FE & $\begin{array}{c}0.49 \\
(1.06)\end{array}$ & FE & $\begin{array}{c}-0.05 \\
(-0.11)\end{array}$ & FE \\
\hline $\mathrm{BE}$ & $\begin{array}{c}1.15 \\
(2.75)\end{array}$ & $\begin{array}{c}2.47 \\
(3.50)\end{array}$ & & & & & $\begin{array}{c}1.32 \\
(3.27)\end{array}$ & $\begin{array}{c}2.46 \\
(3.71)\end{array}$ \\
\hline CA & $\begin{array}{c}2.23 \\
(4.29)\end{array}$ & $\begin{array}{c}0.72 \\
(1.16)\end{array}$ & & & & & $\begin{array}{c}1.62 \\
(4.85)\end{array}$ & $\begin{array}{c}0.61 \\
(1.08)\end{array}$ \\
\hline $\mathrm{DE}$ & $\begin{array}{c}0.73 \\
(1.57)\end{array}$ & $\begin{array}{c}-0.32 \\
(-2.04)\end{array}$ & & & & & $\begin{array}{c}0.13 \\
(0.37)\end{array}$ & $\begin{array}{c}-0.41 \\
(-1.98)\end{array}$ \\
\hline ES & $\begin{array}{c}0.95 \\
(1.31)\end{array}$ & $\begin{array}{c}1.24 \\
(1.92)\end{array}$ & & & & & $\begin{array}{c}2.57 \\
(3.52)\end{array}$ & $\begin{array}{c}1.58 \\
(3.85)\end{array}$ \\
\hline FR & $\begin{array}{c}0.98 \\
(2.67)\end{array}$ & $\begin{array}{c}1.14 \\
(4.31)\end{array}$ & & & & & $\begin{array}{c}0.88 \\
(2.60)\end{array}$ & $\begin{array}{c}1.16 \\
(4.41)\end{array}$ \\
\hline GB & $\begin{array}{c}0.04 \\
(0.09)\end{array}$ & $\begin{array}{c}0.48 \\
(2.56)\end{array}$ & & & & & $\begin{array}{c}-0.48 \\
(-1.09)\end{array}$ & $\begin{array}{c}0.31 \\
(1.58)\end{array}$ \\
\hline IT & $\begin{array}{c}1.06 \\
(0.81)\end{array}$ & $\begin{array}{c}2.98 \\
(3.42)\end{array}$ & & & & & $\begin{array}{c}2.60 \\
(2.77)\end{array}$ & $\begin{array}{c}3.26 \\
(4.32)\end{array}$ \\
\hline JP & $\begin{array}{c}0.35 \\
(1.45)\end{array}$ & $\begin{array}{c}0.37 \\
(3.67)\end{array}$ & & & & & $\begin{array}{c}0.13 \\
(0.54)\end{array}$ & $\begin{array}{c}0.37 \\
(4.12)\end{array}$ \\
\hline NL & $\begin{array}{c}0.84 \\
(2.26)\end{array}$ & $\begin{array}{c}0.34 \\
(2.16)\end{array}$ & & & & & $\begin{array}{c}0.33 \\
(1.29)\end{array}$ & $\begin{array}{c}0.23 \\
(1.12)\end{array}$ \\
\hline US & $\begin{array}{c}0.95 \\
(1.79) \\
\end{array}$ & $\begin{array}{c}-0.15 \\
(-0.55) \\
\end{array}$ & & & & & $\begin{array}{c}0.17 \\
(0.39)\end{array}$ & $\begin{array}{c}-0.29 \\
(-0.79)\end{array}$ \\
\hline CDS_i & & & $\begin{array}{c}-0.03 \\
(-3.92)\end{array}$ & $\begin{array}{c}-0.02 \\
(-3.18) \\
\end{array}$ & $\begin{array}{c}-0.03 \\
(-3.92) \\
\end{array}$ & $\begin{array}{c}-0.02 \\
(-3.18) \\
\end{array}$ & $\begin{array}{c}-0.03 \\
(-4.91) \\
\end{array}$ & $\begin{array}{c}-0.03 \\
(-3.85) \\
\end{array}$ \\
\hline $\mathrm{r} 2$ & $5 \%$ & $29 \%$ & $14 \%$ & $25 \%$ & $14 \%$ & $25 \%$ & $23 \%$ & $34 \%$ \\
\hline \# of Obs & 3910 & 3910 & 3910 & 3910 & 3910 & 3910 & 3910 & 3910 \\
\hline
\end{tabular}




\section{Table 8 - Crisis Analysis}

Table 8 documents the regression of the NI-spread (the difference of yields between a hypothetical 10year bond priced by the older bonds' curve minus its newly issued counterpart), i.e., $N I-$ spread $=$ $y^{\text {hyp }}-y^{\text {actual }}=\frac{\text { price }^{\text {hyp }}-\text { price }}{\text { prictual }}$ hyp $_{\text {duration }}$, on measures of a common liquidity factor and a flight to quality factor across 10 developed countries over three sample periods, crises, pre-2007 crises and post 2007 crises during 1998-2015. Specifically, we run variants of the following regression model:

$$
\mathrm{NI}_{i t}=\alpha+\beta_{i} F_{t}+\gamma\left(C D S_{i t}-\frac{1}{N} \sum_{i=1}^{N} C D S_{i t}\right)+\varepsilon_{i t}
$$

where we model a common component to liquidity, $F_{t}$, by taking a median of the NI-spreads, $F_{t}=$ median $\left(\left\{N I_{i t}\right\}_{i}\right)$, and we choose $\left(C D S_{i t}-\frac{1}{N} \sum_{i}^{N} C D S_{i t}\right)$ as a measure of the relative credit quality across the $N$ countries.

Table 8A All Crisis: Common Factor and Price Pressure

\begin{tabular}{|c|c|c|c|c|c|c|c|c|}
\hline & 1 & 2 & 3 & 4 & 5 & 6 & 7 & 8 \\
\hline Intercept & $\begin{array}{c}-0.05 \\
(-0.06)\end{array}$ & FE & $\begin{array}{c}-0.18 \\
(-0.30) \\
\end{array}$ & $\mathrm{FE}$ & $\begin{array}{c}2.01 \\
(3.24)\end{array}$ & FE & $\begin{array}{c}-0.05 \\
(-0.08) \\
\end{array}$ & FE \\
\hline $\mathrm{BE}$ & $\begin{array}{c}0.91 \\
(4.51)\end{array}$ & $\begin{array}{c}1.58 \\
(4.28)\end{array}$ & & & & & $\begin{array}{c}0.91 \\
(4.93)\end{array}$ & $\begin{array}{c}1.51 \\
(4.60)\end{array}$ \\
\hline CA & $\begin{array}{c}1.00 \\
(6.50)\end{array}$ & $\begin{array}{c}0.38 \\
(1.03)\end{array}$ & & & & & $\begin{array}{c}0.97 \\
(7.77)\end{array}$ & $\begin{array}{c}0.49 \\
(1.51)\end{array}$ \\
\hline DE & $\begin{array}{c}0.43 \\
(2.56)\end{array}$ & $\begin{array}{c}-0.13 \\
(-1.02)\end{array}$ & & & & & $\begin{array}{c}0.41 \\
(2.92)\end{array}$ & $\begin{array}{c}-0.02 \\
(-0.21)\end{array}$ \\
\hline ES & $\begin{array}{c}0.83 \\
(4.47)\end{array}$ & $\begin{array}{c}0.97 \\
(3.82)\end{array}$ & & & & & $\begin{array}{c}0.87 \\
(5.60)\end{array}$ & $\begin{array}{c}0.72 \\
(3.81)\end{array}$ \\
\hline FR & $\begin{array}{c}0.66 \\
(4.04)\end{array}$ & $\begin{array}{c}0.84 \\
(8.41)\end{array}$ & & & & & $\begin{array}{c}0.66 \\
(4.62)\end{array}$ & $\begin{array}{c}0.87 \\
(8.57)\end{array}$ \\
\hline GB & $\begin{array}{c}0.85 \\
(5.72)\end{array}$ & $\begin{array}{c}1.02 \\
(10.07)\end{array}$ & & & & & $\begin{array}{c}0.81 \\
(7.07)\end{array}$ & $\begin{array}{c}1.07 \\
(9.28)\end{array}$ \\
\hline IT & $\begin{array}{c}1.66 \\
(6.38)\end{array}$ & $\begin{array}{c}2.74 \\
(6.62)\end{array}$ & & & & & $\begin{array}{c}1.71 \\
(7.10)\end{array}$ & $\begin{array}{c}2.46 \\
(8.24)\end{array}$ \\
\hline JP & $\begin{array}{c}-0.35 \\
(-2.09)\end{array}$ & $\begin{array}{c}-0.34 \\
(-2.47)\end{array}$ & & & & & $\begin{array}{c}-0.29 \\
(-1.87)\end{array}$ & $\begin{array}{c}-0.24 \\
(-1.61)\end{array}$ \\
\hline NL & $\begin{array}{c}1.69 \\
(8.68)\end{array}$ & $\begin{array}{c}1.38 \\
(10.18)\end{array}$ & & & & & $\begin{array}{c}1.68 \\
(9.35)\end{array}$ & $\begin{array}{c}1.45 \\
(10.53)\end{array}$ \\
\hline US & $\begin{array}{r}1.89 \\
(6.18) \\
\end{array}$ & $\begin{array}{c}1.12 \\
(6.61) \\
\end{array}$ & & & & & $\begin{array}{r}1.84 \\
(6.39) \\
\end{array}$ & $\begin{array}{c}1.25 \\
(5.62)\end{array}$ \\
\hline CDS_i & & & $\begin{array}{c}-0.03 \\
(-4.28) \\
\end{array}$ & $\begin{array}{c}-0.03 \\
(-4.16)\end{array}$ & $\begin{array}{c}-0.04 \\
(-3.86)\end{array}$ & $\begin{array}{c}-0.03 \\
(-3.11) \\
\end{array}$ & $\begin{array}{c}-0.03 \\
(-4.14)\end{array}$ & $\begin{array}{c}-0.02 \\
(-3.64)\end{array}$ \\
\hline $\mathrm{r} 2$ & $31 \%$ & $48 \%$ & $20 \%$ & $33 \%$ & $12 \%$ & $22 \%$ & $42 \%$ & $52 \%$ \\
\hline \# of Obs & 3700 & 3700 & 2063 & 2063 & 3700 & 3700 & 3700 & 3700 \\
\hline
\end{tabular}


Table 8B LTCM: Common Factor and Price Pressure

\begin{tabular}{|c|c|c|c|c|c|c|c|c|}
\hline & 1 & 2 & 3 & 4 & 5 & 6 & 7 & 8 \\
\hline Intercept & $\begin{array}{c}0.00 \\
(1.21)\end{array}$ & FE & $\begin{array}{c}4.42 \\
(6.78)\end{array}$ & $\mathrm{FE}$ & $\begin{array}{c}4.42 \\
(6.78)\end{array}$ & FE & $\begin{array}{c}0.86 \\
(1.22)\end{array}$ & $\mathrm{FE}$ \\
\hline $\mathrm{BE}$ & $\begin{array}{c}0.78 \\
(4.12)\end{array}$ & $\begin{array}{c}0.55 \\
(3.47)\end{array}$ & & & & & $\begin{array}{c}0.76 \\
(3.99)\end{array}$ & $\begin{array}{c}0.55 \\
(3.46)\end{array}$ \\
\hline CA & $\begin{array}{c}0.82 \\
(5.63)\end{array}$ & $\begin{array}{c}0.46 \\
(3.38)\end{array}$ & & & & & $\begin{array}{c}0.78 \\
(4.92)\end{array}$ & $\begin{array}{c}0.46 \\
(3.33)\end{array}$ \\
\hline $\mathrm{DE}$ & $\begin{array}{c}0.29 \\
(1.84)\end{array}$ & $\begin{array}{c}0.01 \\
(0.11)\end{array}$ & & & & & $\begin{array}{c}0.27 \\
(1.70)\end{array}$ & $\begin{array}{c}0.01 \\
(0.15)\end{array}$ \\
\hline ES & $\begin{array}{c}0.69 \\
(3.69)\end{array}$ & $\begin{array}{c}1.45 \\
(17.70)\end{array}$ & & & & & $\begin{array}{c}0.68 \\
(3.57)\end{array}$ & $\begin{array}{c}1.44 \\
(17.60)\end{array}$ \\
\hline FR & $\begin{array}{c}0.47 \\
(2.46)\end{array}$ & $\begin{array}{c}1.07 \\
(4.21)\end{array}$ & & & & & $\begin{array}{c}0.45 \\
(2.31)\end{array}$ & $\begin{array}{c}1.07 \\
(4.28)\end{array}$ \\
\hline GB & $\begin{array}{c}0.69 \\
(4.85)\end{array}$ & $\begin{array}{c}0.49 \\
(4.48)\end{array}$ & & & & & $\begin{array}{c}0.66 \\
(4.29)\end{array}$ & $\begin{array}{c}0.50 \\
(4.48)\end{array}$ \\
\hline IT & $\begin{array}{c}1.52 \\
(5.95)\end{array}$ & $\begin{array}{c}2.17 \\
(15.18)\end{array}$ & & & & & $\begin{array}{c}1.53 \\
(6.16)\end{array}$ & $\begin{array}{c}2.16 \\
(15.15)\end{array}$ \\
\hline JP & $\begin{array}{c}-0.56 \\
(-3.60)\end{array}$ & $\begin{array}{c}-0.64 \\
(-3.19)\end{array}$ & & & & & $\begin{array}{c}-0.40 \\
(-1.74)\end{array}$ & $\begin{array}{c}-0.65 \\
(-3.08)\end{array}$ \\
\hline NL & $\begin{array}{c}1.57 \\
(9.07)\end{array}$ & $\begin{array}{c}1.59 \\
(9.85)\end{array}$ & & & & & $\begin{array}{c}1.57 \\
(9.07)\end{array}$ & $\begin{array}{c}1.60 \\
(9.60)\end{array}$ \\
\hline US & $\begin{array}{c}1.82 \\
(7.12)\end{array}$ & $\begin{array}{c}0.94 \\
(2.54) \\
\end{array}$ & & & & & $\begin{array}{c}1.78 \\
(7.43) \\
\end{array}$ & $\begin{array}{c}0.94 \\
(2.56)\end{array}$ \\
\hline CDS_i & & & $\begin{array}{c}-0.37 \\
(-3.66)\end{array}$ & $\begin{array}{c}0.07 \\
(0.71) \\
\end{array}$ & $\begin{array}{c}-0.37 \\
(-3.66)\end{array}$ & $\begin{array}{c}0.07 \\
(0.71) \\
\end{array}$ & $\begin{array}{c}-0.07 \\
(-0.79) \\
\end{array}$ & $\begin{array}{c}-0.02 \\
(-0.31)\end{array}$ \\
\hline $\mathrm{r} 2$ & $54 \%$ & $60 \%$ & $12 \%$ & $38 \%$ & $12 \%$ & $38 \%$ & $55 \%$ & $60 \%$ \\
\hline \# of Obs & 1840 & 1840 & 1840 & 1840 & 1840 & 1840 & 1840 & 1840 \\
\hline
\end{tabular}


Table 8C Other Crises: Common Factor and Price Pressure

\begin{tabular}{|c|c|c|c|c|c|c|c|c|}
\hline & 1 & 2 & 3 & 4 & 5 & 6 & 7 & 8 \\
\hline Intercept & $\begin{array}{c}-0.33 \\
(-0.37)\end{array}$ & $\mathrm{FE}$ & $\begin{array}{c}-0.36 \\
(-0.55) \\
\end{array}$ & $\mathrm{FE}$ & $\begin{array}{c}-0.36 \\
(-0.55)\end{array}$ & FE & $\begin{array}{c}-0.33 \\
(-0.52) \\
\end{array}$ & $\mathrm{FE}$ \\
\hline $\mathrm{BE}$ & $\begin{array}{c}-0.02 \\
(-0.01)\end{array}$ & $\begin{array}{c}-0.36 \\
(-1.04)\end{array}$ & & & & & $\begin{array}{c}0.30 \\
(0.34)\end{array}$ & $\begin{array}{c}-0.11 \\
(-0.31)\end{array}$ \\
\hline $\mathrm{CA}$ & $\begin{array}{c}1.39 \\
(1.29)\end{array}$ & $\begin{array}{c}1.69 \\
(2.81)\end{array}$ & & & & & $\begin{array}{c}0.92 \\
(1.35)\end{array}$ & $\begin{array}{c}1.29 \\
(2.33)\end{array}$ \\
\hline $\mathrm{DE}$ & $\begin{array}{c}-0.28 \\
(-0.35)\end{array}$ & $\begin{array}{c}-0.03 \\
(-0.24)\end{array}$ & & & & & $\begin{array}{c}-0.59 \\
(-1.42)\end{array}$ & $\begin{array}{c}-0.31 \\
(-1.54)\end{array}$ \\
\hline ES & $\begin{array}{c}0.02 \\
(0.03)\end{array}$ & $\begin{array}{c}0.00 \\
(0.00)\end{array}$ & & & & & $\begin{array}{c}1.14 \\
(1.19)\end{array}$ & $\begin{array}{c}0.91 \\
(1.57)\end{array}$ \\
\hline FR & $\begin{array}{c}1.31 \\
(8.17)\end{array}$ & $\begin{array}{c}1.29 \\
(7.86)\end{array}$ & & & & & $\begin{array}{c}1.41 \\
(7.26)\end{array}$ & $\begin{array}{c}1.34 \\
(7.62)\end{array}$ \\
\hline GB & $\begin{array}{c}0.57 \\
(1.06)\end{array}$ & $\begin{array}{c}0.47 \\
(1.64)\end{array}$ & & & & & $\begin{array}{c}0.00 \\
(0.00)\end{array}$ & $\begin{array}{c}0.04 \\
(0.12)\end{array}$ \\
\hline IT & $\begin{array}{c}0.89 \\
(0.44)\end{array}$ & $\begin{array}{c}0.41 \\
(0.55)\end{array}$ & & & & & $\begin{array}{c}1.97 \\
(2.22)\end{array}$ & $\begin{array}{c}1.31 \\
(2.50)\end{array}$ \\
\hline JP & $\begin{array}{c}0.59 \\
(7.62)\end{array}$ & $\begin{array}{c}0.61 \\
(6.42)\end{array}$ & & & & & $\begin{array}{c}0.37 \\
(1.18)\end{array}$ & $\begin{array}{c}0.42 \\
(2.54)\end{array}$ \\
\hline NL & $\begin{array}{c}0.47 \\
(0.64)\end{array}$ & $\begin{array}{c}0.61 \\
(1.88)\end{array}$ & & & & & $\begin{array}{c}0.09 \\
(0.21)\end{array}$ & $\begin{array}{c}0.31 \\
(1.22)\end{array}$ \\
\hline US & $\begin{array}{c}-0.51 \\
(-0.59)\end{array}$ & $\begin{array}{c}-0.23 \\
(-0.86)\end{array}$ & & & & & $\begin{array}{c}-1.17 \\
(-2.56)\end{array}$ & $\begin{array}{c}-0.76 \\
(-1.79)\end{array}$ \\
\hline CDS_i & & & $\begin{array}{c}-0.03 \\
(-4.27) \\
\end{array}$ & $\begin{array}{c}-0.02 \\
(-3.98) \\
\end{array}$ & $\begin{array}{c}-0.03 \\
(-4.27) \\
\end{array}$ & $\begin{array}{c}-0.02 \\
(-3.98) \\
\end{array}$ & $\begin{array}{c}-0.04 \\
(-4.38) \\
\end{array}$ & $\begin{array}{c}-0.02 \\
(-3.97) \\
\end{array}$ \\
\hline $\mathrm{r} 2$ & $1 \%$ & $34 \%$ & $20 \%$ & $38 \%$ & $20 \%$ & $38 \%$ & $23 \%$ & $40 \%$ \\
\hline \# of Obs & 1860 & 1860 & 1860 & 1860 & 1860 & 1860 & 1860 & 1860 \\
\hline
\end{tabular}




\section{Table 9 - Price Staleness and Lead-Lag}

Table 9 documents the autocorrelation of changes in a hypothetical bond priced by the older bonds' curve and in its newly issued counterpart for the 10-year bond across 10 developed countries over the period 1998-2015. The represented countries are BE (Belgium), CA (Canada), DE (Germany), ES (Spain), FR (France), GB (United Kingdom), IT (Italy), JP (Japan), NL (Netherlands) and US (United States).

Price Staleness and Lead-Lag between New and Old Bond

\begin{tabular}{lcccccccccc}
\hline & BE & CA & DE & ES & FR & GB & IT & JP & NL & US \\
\hline New Bond rho(1) & -0.06 & -0.02 & -0.03 & -0.09 & -0.04 & -0.07 & -0.11 & 0.06 & -0.04 & -0.03 \\
Old Bond rho(1) & -0.05 & -0.06 & -0.03 & -0.06 & -0.03 & -0.06 & -0.11 & 0.02 & -0.04 & -0.03 \\
Difference & -0.01 & 0.03 & 0.00 & -0.03 & -0.01 & -0.01 & 0.00 & 0.04 & 0.01 & 0.00 \\
& $(-0.26)$ & $(2.82)$ & $(0.56)$ & $(-1.60)$ & $(-0.55)$ & $(-0.81)$ & $(0.00)$ & $(1.04)$ & $(0.56)$ & $(-0.22)$ \\
\hline New Bond lead & -0.06 & -0.05 & -0.03 & -0.07 & -0.03 & -0.06 & -0.09 & 0.06 & -0.03 & -0.03 \\
Old Bond lead & -0.05 & -0.02 & -0.02 & -0.07 & -0.03 & -0.05 & -0.11 & 0.03 & -0.03 & -0.03 \\
Difference & -0.01 & -0.02 & 0.00 & 0.00 & 0.01 & -0.01 & 0.02 & 0.03 & 0.00 & 0.00 \\
& $(-0.69)$ & $(-0.69)$ & $(-0.69)$ & $(-0.69)$ & $(-0.69)$ & $(-0.69)$ & $(-0.69)$ & $(-0.69)$ & $(-0.69)$ & $(-0.69)$ \\
\hline \# of Obs & 910 & 910 & 910 & 910 & 910 & 910 & 910 & 910 & 910 & 1171 \\
\hline
\end{tabular}




\section{Table 10 - CDS and Flows}

Table 10 documents the contemporaneous correlation pattern between the change in the crosssectionally demeaned CDS premium, i.e., $\Delta\left(C D S_{i t}-\frac{1}{N} \sum_{i}^{N} C D S_{i t}\right)$ and net flows of sovereign government bonds across 10 developed countries from November 2005-2015. The data on net flows is provided by State Street Corporation. For State Street data, each transaction in a country's sovereign government bonds are calculated as the difference in dollar value of buys minus sells at a given time $t$. State Street then takes a 5-day exponential average of these net flows and converts these flows into a percentile based on the last five years of data. The represented countries are BE (Belgium), CA (Canada), DE (Germany), ES (Spain), FR (France), GB (United Kingdom), IT (Italy), JP (Japan), NL (Netherlands) and US (United States). The table reports the correlation pattern using the State Street data for 1-month, quarterly and semi-annual changes of the CDS premium and net flows.

Correlation of DCDS and State Street Net Flows

\begin{tabular}{lcccccccccc}
\hline & BE & CA & DE & ES & FR & GB & IT & JP & NL & US \\
\hline 1 Month & -0.10 & -0.03 & -0.10 & -0.20 & 0.01 & -0.10 & -0.24 & -0.07 & -0.17 & -0.11 \\
3 Month & -0.22 & -0.05 & -0.04 & -0.29 & -0.03 & -0.12 & -0.37 & -0.11 & -0.34 & -0.15 \\
6 Month & -0.34 & -0.14 & -0.12 & -0.44 & -0.04 & -0.10 & -0.51 & -0.20 & -0.34 & -0.23 \\
\hline
\end{tabular}




\section{Table 11 - Common Factor, Flight to Quality and Net Flows}

Table 11 investigates the relation between newly issued (NI) spreads, a common liquidity factor, a flight to quality factor and sovereign government bond net flows. Table 11A documents the regression of the NI-spread (the difference of yields between a hypothetical 10-year bond priced by the older bonds' curve minus its newly issued counterpart), i.e. $N I-$ spread $=y^{\text {hyp }}-y^{\text {actual }}=\frac{\text { price }^{\text {hyp }} \text {-price actual }}{\text { price }^{\text {hyp }} \text { duration }}$, on measures of a common liquidity factor, a flight to quality factor across 10 developed countries, and a measure of net flows of the sovereign bond (from State Street Asssociates) over the period 2005-2015. Specifically, we run variants of the following regression model:

$$
\mathrm{NI}_{i t}=\alpha+\beta_{i} F_{t}+\gamma\left(C D S_{i t}-\frac{1}{N} \sum_{i=1}^{N} C D S_{i t}\right)+\lambda \sum_{j=-6}^{+6} N F_{i t+j}+\varepsilon_{i t}
$$

where we model a common component to liquidity, $F_{t}$, by taking a median of the NI-spreads (measured against the past 5 -years of data), $F_{t}=\operatorname{median}\left(\left\{N I_{i t}\right\}_{i}\right)$, we choose $\left(C D S_{i t}-\frac{1}{N} \sum_{i}^{N} C D S_{i t}\right)$ as a measure of the relative credit quality (i.e., flight to quality) across the $N$ countries (measured against the past 5 years of data), and $N F_{i t+j}$ a 5-day exponential average of the difference in dollar value of buys minus sells of the sovereign bond at a given time $t+j$, converted into a percentile based on the last five years of data. Table 11B reports a regression of the flight to quality factor against the net flows factor. 
Table 11A: Relating NI Spread to Common Liquidity, Flight to Quality, and Cumulative Net Flows (+-6 Weeks)

\begin{tabular}{|c|c|c|c|c|c|c|c|c|}
\hline & 1 & 2 & 3 & 4 & 5 & 6 & 7 & 8 \\
\hline Intercept & $\begin{array}{c}-1.91 \\
(-2.10)\end{array}$ & $\mathrm{FE}$ & $\begin{array}{c}-0.11 \\
(-0.33)\end{array}$ & $\mathrm{FE}$ & $\begin{array}{c}-1.81 \\
(-2.19) \\
\end{array}$ & $\mathrm{FE}$ & $\begin{array}{c}-1.37 \\
(-1.85)\end{array}$ & $\mathrm{FE}$ \\
\hline $\mathrm{BE}$ & & & & & & & $\begin{array}{c}2.34 \\
(6.07)\end{array}$ & $\begin{array}{c}2.28 \\
(5.05)\end{array}$ \\
\hline $\mathrm{CA}$ & & & & & & & $\begin{array}{c}1.70 \\
(6.36)\end{array}$ & $\begin{array}{c}1.86 \\
(4.45)\end{array}$ \\
\hline $\mathrm{DE}$ & & & & & & & $\begin{array}{c}0.23 \\
(0.94)\end{array}$ & $\begin{array}{c}0.07 \\
(0.34)\end{array}$ \\
\hline ES & & & & & & & $\begin{array}{c}0.80 \\
(1.61)\end{array}$ & $\begin{array}{c}1.28 \\
(3.39)\end{array}$ \\
\hline FR & & & & & & & $\begin{array}{c}0.82 \\
(2.70)\end{array}$ & $\begin{array}{c}0.90 \\
(3.33)\end{array}$ \\
\hline GB & & & & & & & $\begin{array}{c}0.86 \\
(3.39)\end{array}$ & $\begin{array}{c}0.66 \\
(2.85)\end{array}$ \\
\hline IT & & & & & & & $\begin{array}{c}1.89 \\
(3.97)\end{array}$ & $\begin{array}{c}2.26 \\
(6.16)\end{array}$ \\
\hline JP & & & & & & & $\begin{array}{c}0.26 \\
(1.68)\end{array}$ & $\begin{array}{c}0.24 \\
(1.63)\end{array}$ \\
\hline NL & & & & & & & $\begin{array}{c}0.52 \\
(1.00)\end{array}$ & $\begin{array}{c}0.29 \\
(0.81)\end{array}$ \\
\hline US & & & & & & & $\begin{array}{c}1.12 \\
(3.42)\end{array}$ & $\begin{array}{c}0.69 \\
(2.61)\end{array}$ \\
\hline CDS_i & & & $\begin{array}{c}-0.03 \\
(-4.56) \\
\end{array}$ & $\begin{array}{c}-0.03 \\
(-4.87) \\
\end{array}$ & $\begin{array}{c}-0.03 \\
(-4.61) \\
\end{array}$ & $\begin{array}{c}-0.03 \\
(-4.80) \\
\end{array}$ & $\begin{array}{c}-0.03 \\
(-4.52) \\
\end{array}$ & $\begin{array}{c}-0.03 \\
(-4.95) \\
\end{array}$ \\
\hline Flow_i & $\begin{array}{c}0.06 \\
(2.08)\end{array}$ & $\begin{array}{c}0.06 \\
(2.05)\end{array}$ & & & $\begin{array}{c}0.05 \\
(2.09) \\
\end{array}$ & $\begin{array}{c}0.05 \\
(1.71)\end{array}$ & $\begin{array}{c}0.05 \\
(2.21)\end{array}$ & $\begin{array}{c}0.04 \\
(1.70)\end{array}$ \\
\hline $\mathrm{r} 2$ & $1 \%$ & $2 \%$ & $10 \%$ & $13 \%$ & $11 \%$ & $14 \%$ & $18 \%$ & $21 \%$ \\
\hline \# of Obs & 4830 & 4830 & 4830 & 4830 & 4830 & 4830 & 4830 & 4830 \\
\hline
\end{tabular}

Table 11b Relating Net Flows to Flight to Quality

\begin{tabular}{lcc}
\hline & Flows (-6W to $+6 \mathrm{~W})$ & Current $(0 \mathrm{~W})$ \\
\hline CDS_i & -1.22 & -0.14 \\
$(\mathrm{x} 100)$ & $(-1.55)$ & $(-2.03)$ \\
\hline $\mathrm{r} 2$ & $6 \%$ & $2 \%$ \\
\# of Obs & 4830 & 4830 \\
\hline
\end{tabular}




\section{FIGURE 1: Newly Issued Bond Spreads}

Figure 1 graphs the spread between the newly issued and latest issue likewise bond, as well as the New Issue (NI)spread (the difference between a hypothetical bond priced by the older bonds' curve minus its newly issued

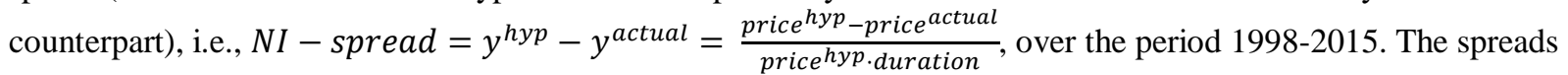
are graphed with the slope between the 2-year and 10-year government bond yields labelled on the right-hand side. The represented countries are BD (Germany), BG (Belgium), CN (Canada), ES (Spain), FR (France), IT (Italy), JP (japan), NL (Netherlands), UK (United Kingdom) and US (United States).
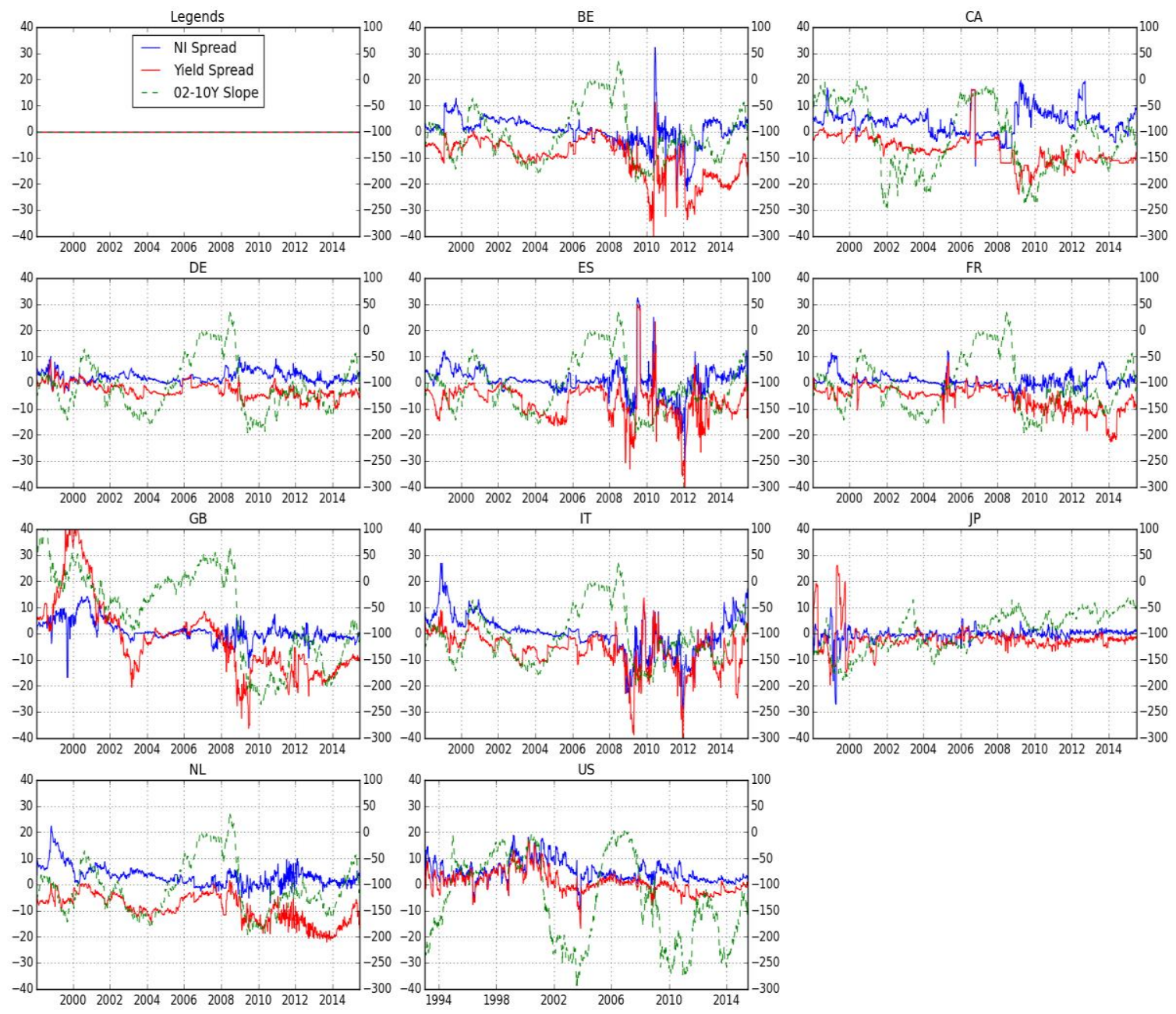


\section{FIGURE 2: Cross-Sectional Pricing of New Issue Spreads}

Figure 2 plots the average NI-spread for ten developed countries against (i) the factor loading of the NIspreads on a common liquidity factor, scaled by the average of the common liquidity factor, and (ii) the above variable plus the average cross-sectionally demeaned CDS of the country, scaled by the pooled regression coefficient. The period covers the 1998-2015 sample. The represented countries are Belgium, Canada, Germany, Spain, France, United Kingdom, Italy, Japan, Netherlands and United States. The NIspread is defined as the difference of yields between a hypothetical 10-year bond priced by the older bonds' curve minus its newly issued counterpart), i.e. $N I-$ spread $=y^{\text {hyp }}-y^{\text {actual }}=\frac{\text { price }^{\text {hyp }}-\text { price }}{\text { actual }}$; the common liquidity factor is taken as a median of the NI-spreads, median $\left(\left\{N I_{i t}\right\}_{i}\right)$, and the cross-sectionally demeaned CDS equals $\left(C D S_{i t}-\frac{1}{N} \sum_{i}^{N} C D S_{i t}\right)$ and is a measure of the relative credit quality across the $N$ countries.

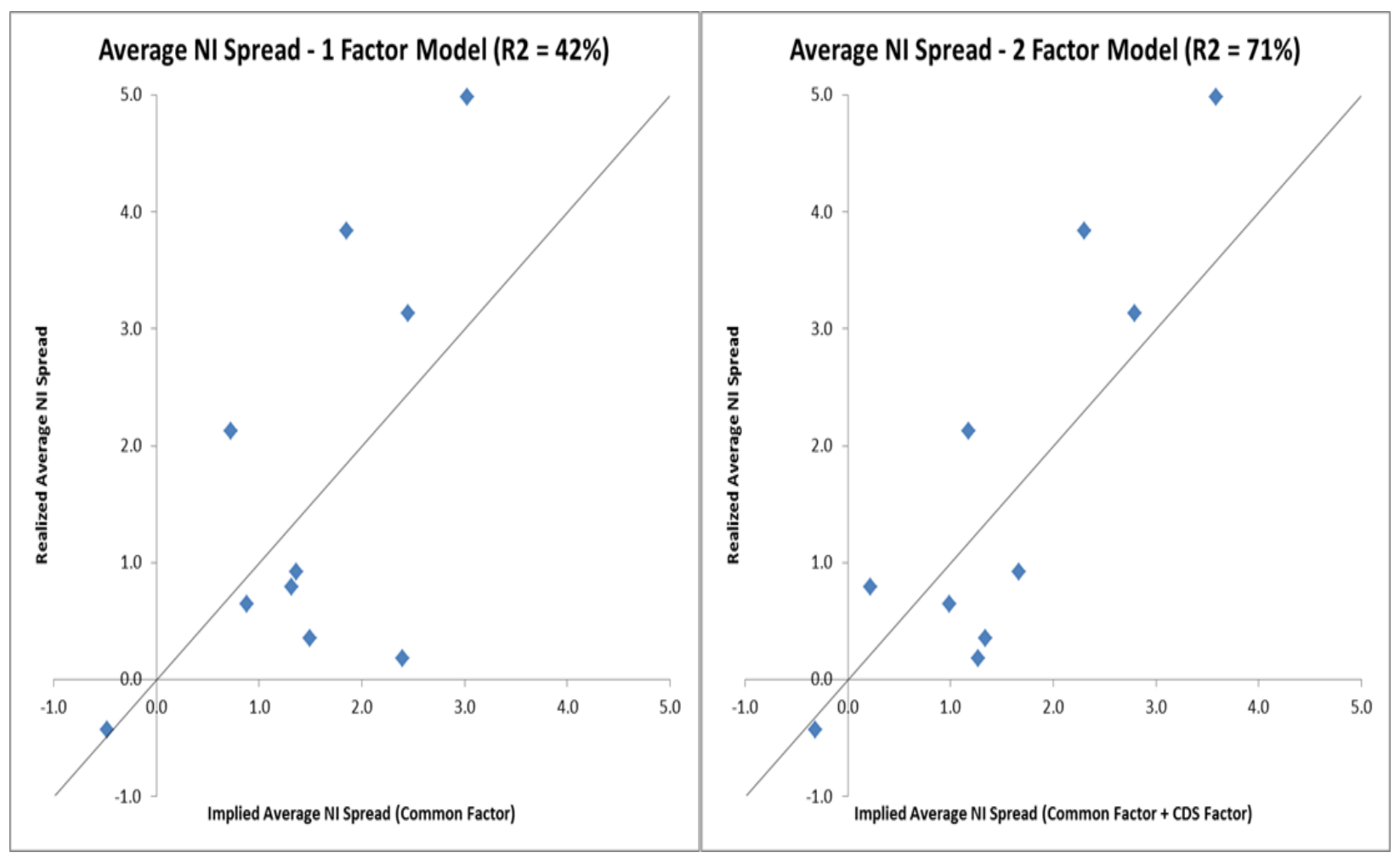




\section{FIGURE 3: Crisis Period Identification}

Figure 3 plots the crisis periods over the 1998-2015 sample. A crisis is defined as an event representing a 3 standard deviation move of the rolling 1-year standard deviation of weekly changes in the St. Louis Fed Financial Stress Index index. Figure 3 plots the crisis periods over the full sample.

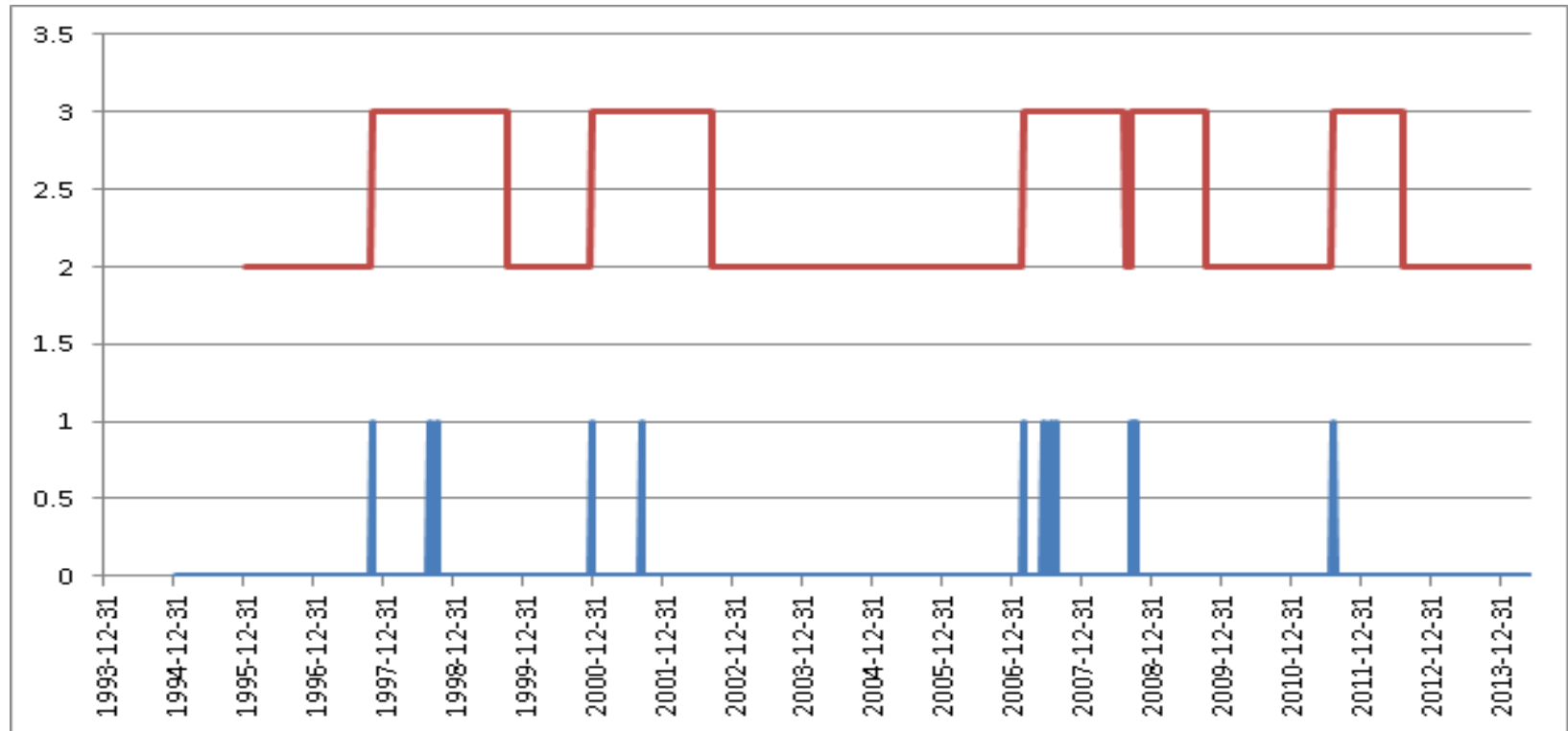




\section{FIGURE 4: Impulse Response of Shocks to NI-Spreads During Extreme Periods}

Figure 4 presents the impulse response functions for a threshold autoregressive model of order 1 . The threshold autoregressive model (e.g., Tong and Lim (1980)) for the NI-spread represents a pooled timeseries across 10 developed countries with three thresholds - a low (i.e., <0 basis points), middle (i.e. between 0 and 5 basis points), and high (i.e., greater than 5 basis points) range of NI-spreads. The NIspread for each country is defined as the difference of yields between a hypothetical 10-year bond priced by the older bonds' curve minus its newly issued counterpart), i.e., NI - spread $=y^{\text {hyp }}-$ $y^{\text {actual }}=\frac{\text { price } e^{\text {hyp}}-\text { price } e^{\text {actual }}}{\text { price }}$.

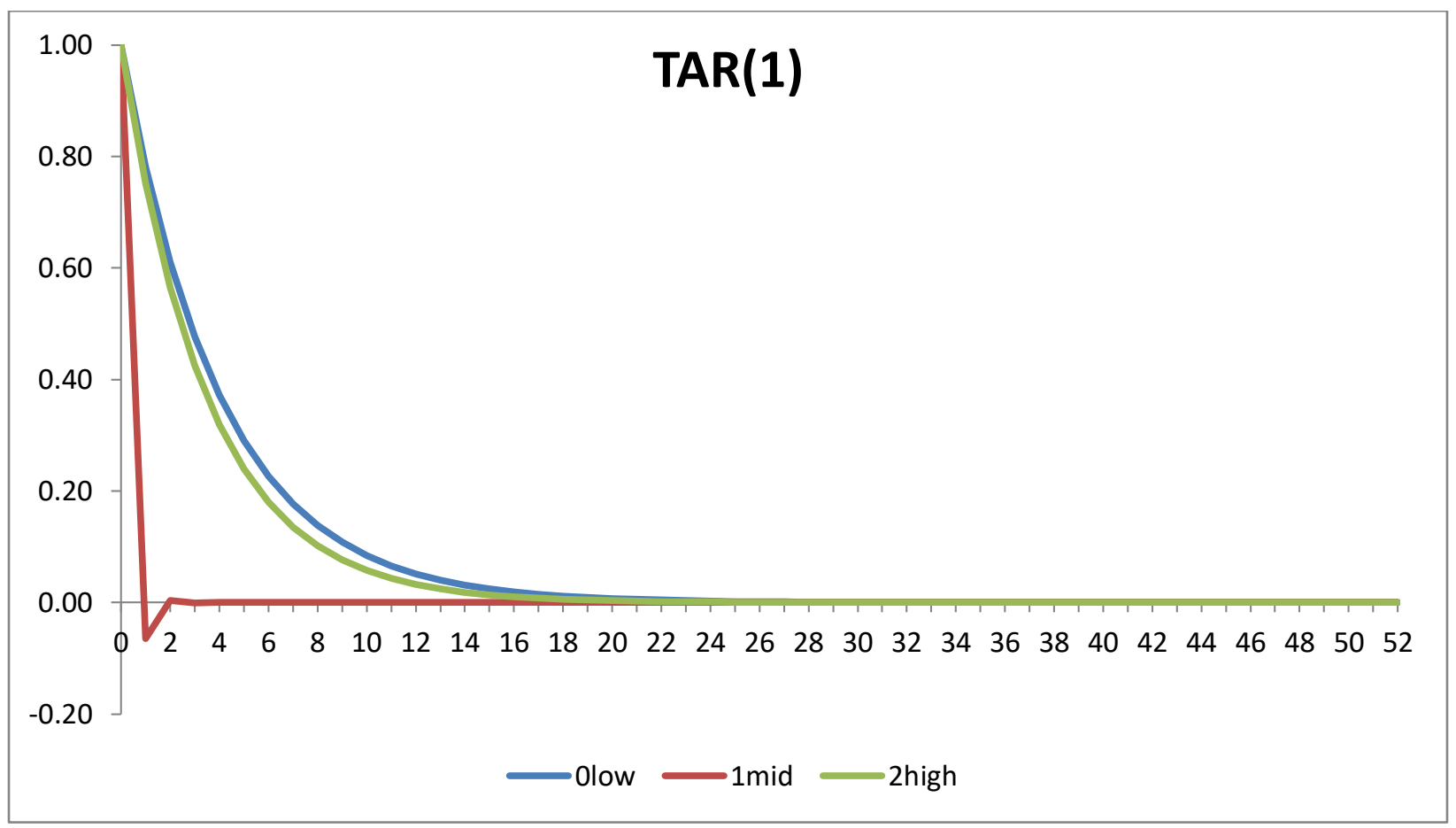

